\title{
Shareholder Value Effects of Ethical Sourcing: Comparing Reactive and Proactive Initiatives
}

\author{
Seongtae $\mathrm{Kim}^{1}{ }^{1} \cdot$ Sangho $\mathrm{Chae}^{2}$ (1)
}

Received: 25 August 2020 / Accepted: 11 May 2021 / Published online: 24 May 2021

(c) The Author(s) 2021

\begin{abstract}
With the advent of responsible business, ensuring social responsibility in sourcing is of interest to both academics and practitioners. In this study, we examine one way of achieving this goal: ethical sourcing initiatives (ESIs). ESIs refer to a firm's formal and informal actions to manage sourcing processes in an ethical and socially responsible manner. While ESIs have been established as an important part of corporate social responsibility, it is unclear whether, how, and when this corporate effort is economically beneficial. We conduct an event study estimating the shareholder value effect of 159 publicly traded firms' ESIs and find that the stock market reacts positively to ESIs in general. We also compare market reactions under different conditions including reactive versus proactive ESIs, and their interactions with initiative timing, firm size, and financial risk. Additionally, we find that ESIs are associated with long-term stock price and operating performance. Overall, our findings clarify the potential economic benefits of corporate ESIs and encourage buying firms to take these initiatives selectively according to business contexts.
\end{abstract}

Keywords Ethical sourcing · Socially responsible sourcing $\cdot$ Supply chain $\cdot$ Corporate initiative $\cdot$ Corporate social responsibility $\cdot$ Event study

\section{Introduction}

Ensuring social responsibility in supply chains is of great interest to buying firms. Failure to do so can only damage a firm's reputation and shareholder value (Kim et al., 2019). For example, apparel giants such as Nike experienced huge public backlash in the 1990s after they were caught engaging in child labor at supplier facilities (Zadek, 2004). Starbucks, the coffee retail giant, also received intense media scrutiny and public criticism following allegations of unfair treatment toward their coffee farmers (Argenti, 2004). In the 2010s, Apple, Dell, HP, and Sony had all suffered negative brand

Sangho Chae

s.chae@tilburguniversity.edu

Seongtae Kim

seongtae.kim@aalto.fi

1 Department of Information and Service Management, School of Business, Aalto University, Ekonominaukio 1, 02150 Espoo, Finland

2 Department of Management, School of Economics and Management, Tilburg University, 5037 AB Tilburg, The Netherlands sentiment due to a series of high-profile employee suicides at their supplier, Foxconn, whose factory workers in China had to work long hours in poor working conditions and faced job instability (Dean \& Tsai, 2010; Marchant, 2017).

In line with this, scholars have introduced ethical sourcing initiatives (hereafter, ESIs) as an approach to establishing the social responsibility of suppliers (e.g., Locke \& Romis, 2007; Preuss, 2009; Roberts, 2003). In this study, we refer to ESIs as a firm's formal and informal actions to manage sourcing processes in an ethical and socially responsible manner (Kim et al., 2018). These firm efforts are often discussed as a strategic imperative that enables firms to communicate their corporate social responsibility (CSR) activities to stakeholders and obtain a competitive advantage over their rivals (Eccles et al., 2014; Wagner et al., 2009). For instance, Nike, once vilified for its ethically questionable sourcing practices, is now seen as one of the global CSR leaders with a series of social initiatives (e.g., CSR department established in 1998) to achieve transparency in its global supply chain (Zadek, 2004).

The growing literature on ESIs has focused on many aspects of management such as their scope (Carter \& Jennings, 2002; Spence \& Bourlakis, 2009), implementation 
issues (Preuss, 2009; Roberts, 2003), impacts on the buyer's reputation (Awaysheh \& Klassen, 2010), capability (Foerstl et al., 2010; Reuter et al., 2010), and supplier performance (Blome et al., 2014). However, what has been neglected in the literature is whether, how, and when this corporate effort is economically beneficial. A recent systematic review reveals that very little scholarly attention has been paid to the economic consequences of ESIs (Kim et al., 2018). This lack of research is perplexing given that the field of ethical sourcing has been developed over the decades. Uncertainties regarding the benefits of investing in ESIs would make firms reluctant to genuinely address social matters in the sourcing context, which can harm both the business and society.

Therefore, we investigate in this study the economic effects of ESIs. In the literature, examining economic effects associated with CSR comes down to two major streams of research: "Main Street" and "Wall Street" (Lamin \& Zaheer, 2012). Put simply, the former is about how consumers perceive firms' CSR (e.g., Wagner et al., 2009; Yoon et al., 2006), while the latter is more interested in its investor perception (e.g., Flammer, 2013; Gilley et al., 2000; Kim et al., 2019). Our study focuses on investor behavior towards ESIs, given that one main goal of consumer-based strategies is, after all, to maximize shareholder value. Luo and Bhattacharya $(2006$, p. 1) also argue that "it is important to evaluate CSR's impact on market value (i.e., stock-based firm performance) because a firm's financial health is the ultimate test for success or failure of any strategic initiative." We estimate shareholder value effects associated with ESIs since these effects reflect the true economic value of firms (McWilliams \& Siegel, 1997).

This study also aims to investigate the differential effects of reactive and proactive ESIs on shareholder value. In particular, we argue that the direction and magnitude of the stock market reaction to such ESI strategies vary according to internal and external contextual factors. For example, firms may engage in ESIs, either reactively or proactively, because they possess slack financial resources or are more visible to the general public, eliciting different responses from the stock market. Therefore, research on the economic implications of ESIs needs to account for such contextual factors that possibly moderate the direct causal relationship (Aragón-Correa \& Sharma, 2003). Doing so will reveal under what conditions firms could maximize shareholder value from ESI efforts.

We conduct an event study analysis, followed by regression modeling, using a sample of 159 publicly traded U.S. firms' ESIs. Theorizing ESIs as one mainstay of CSR that reinforces the value chain of the firm (Porter \& Kramer, 2006), we show a positive shareholder value effect of ESIs in general. We then extend the framework by hypothesizing and demonstrating that the direction and magnitude of the shareholder value effect of ESIs depend on how reactive and proactive ESI strategies are utilized under different contextual factors including initiative timing, firm size, and financial risk.

Our study contributes to the growing body of the ESI literature by providing the most convincing empirical evidence yet for the economic value of ESIs. ESIs have been studied in relation to economic benefits such as reputation (Awaysheh \& Klassen, 2010) and supplier performance (Blome et al., 2014); however, their direct impact on shareholder value has not been investigated. Furthermore, our findings provide a more nuanced understanding of the economic value of ESIs by revealing the contingencies around reactive and proactive ESIs. For managers, our study provides clear arguments for implementing ESIs. They not only have positive societal impacts but also can directly reinforce the company's value chain and increase shareholder value. The findings on the contingent effects of reactive and proactive ESIs also offer opportunities for managers to customize ESI strategies to different company settings, contributing to both the business and society.

\section{Literature Review}

\section{Ethical Sourcing Initiatives}

As noted earlier, ESIs refer to a firm's formal and informal implementation of managing sourcing processes in an ethical and socially responsible manner (Kim et al., 2018). While early ethical sourcing efforts concentrated on promoting ethical behaviors of purchasing managers (Browning \& Zabriskie, 1983; Rudelius \& Buchholz, 1979; for a review, see Kim et al., 2018), ESIs nowadays attempt to align overall supply management processes with broad CSR areas including environment, diversity, human rights, health and safety, animal welfare, philanthropy, and fair trade (Carter \& Jennings, 2002). The focus of ESIs in this study is on not only managing the buying firm's supply process (e.g., supplier selection or monitoring) but also incorporating social responsibility criteria such as human rights and health/safety into suppliers (Spence \& Bourlakis, 2009). In that sense, our ESI scope is broader than that of earlier studies that are limited mainly to ethical sourcing policies like codes of conduct (e.g., Preuss, 2009; Roberts, 2003).

Firms can implement ESIs in managing suppliers, particularly in the supplier selection and monitoring process. ESI-based supplier selection is to choose only suppliers who meet ethical and social criteria, often derived from stakeholder requirements (Kim et al., 2018; Roberts, 2003). In this regard, when potential suppliers are unable to fulfill the requirements of stakeholders in respect to such criteria, they might be excluded from the selection process. Supplier monitoring is firms' regular formal and informal assessment of 
suppliers (e.g., auditing, inspection) to ensure that the suppliers meet the criteria. Therefore, if current suppliers cannot meet such criteria or breach the CSR requirements, it might be difficult to maintain the relationship with the buyers. One example is Nike, which discontinued relationships with several suppliers in Indonesia over non-compliance problems (WSJ, 1997). Studies in this stream of literature have found that ESIs on supplier selection and evaluation can help firms develop capabilities to discover and resolve CSR issues of suppliers early (Foerstl et al., 2010; Reuter et al., 2010) and protect company reputation (Awaysheh \& Klassen, 2010).

Ethical sourcing codes of conduct are another form of ESIs, often adopted by firms to communicate their commitment to ethical sourcing and to meet stakeholder expectations for CSR (Kim et al., 2018). These corporate formal written policies are closely related to the supplier selection and monitoring process as they can be reflected in the specific selection and evaluation criteria. Firms can adopt ethical sourcing codes of conduct individually or as joint initiatives involving other firms and governments (Roberts, 2003). Ethical sourcing codes of conduct of large corporations typically cover comprehensive CSR areas, particularly including labor conditions such as employee safety and child/sweatshop labor at supplier locations (Carter \& Jennings, 2002; Preuss, 2009). The main reasons for adopting these codes are not only to respond to pressures from stakeholders but also to create a competitive advantage for the firm through enhanced reputation and impact on society (Preuss, 2009; Roberts, 2003).

Although numerous leading multi-national firms adopt such codes of conduct and the resulting supplier selection and monitoring schemes, scholars also recognize their limitations in extending ethical responsibilities to direct and indirect suppliers (e.g., Frenkel \& Scott, 2002; Knudsen, 2013; Locke \& Romis, 2007; Yu, 2008). The effectiveness of such policies is constrained by two major reasons. The first is insufficient institutional support in the host countries. For example, the Chinese government pays less attention to the protection of labor rights, which leads to weak law enforcement failing to guarantee decent working conditions ( $\mathrm{Yu}$, 2008; Jiang, 2009). This may lead to "supplier-auditor collusion," which then compromises the effectiveness of buying firms' sourcing policies further (Chen et al., 2020). The second is a lack of supplier capabilities. As found by Knudsen (2013), many upstream, particularly lower-tier suppliers, do not have enough resources to properly meet the ethical and social criteria set by the downstream customers.

Consequently, for ESIs to be manifested in practice effectively, firms need to determine optimal sourcing strategies. Scholars have documented that firms can make the best use of sourcing codes and the resulting monitoring when guided by contingency policy (Chen \& Baddam, 2015; Chen et al., 2020). For example, Chen and Baddam (2015) reveal that firms should take a wait-and-see approach when the likelihood of supplier non-compliance is low or when the consequence of that problem is high. Yet, under a changing environment that makes the likelihood of and the consequence of the risks uncertain, firms should take a more proactive sourcing approach such as cutting ties to unethical suppliers in advance before any ethical issues become public. Indeed, reactive and proactive strategies matter to the success of ethical sourcing; but relatively little is known about how stakeholders, particularly investors respond to such firm approaches.

\section{ESI Strategy: Reactive and Proactive}

ESIs can be categorized into reactive and proactive strategies. Reactive ESIs are a firm's ex-post approaches to mitigating the negative consequences of social misconduct by its suppliers. Accordingly, these initiatives are typically used to regain legitimacy, thereby recovering from reputational damages triggered by public criticism (Argenti, 2004; Eccles et al., 2007, 2014; Zadek, 2004). Examples of reactive initiatives include an internal investigation (e.g., ad hoc auditing) against an allegation of suppliers' social misconduct or switching suppliers over the misconduct (e.g., Apple and HP, see Dean \& Tsai, 2010). Prior studies suggest that investors tend to respond positively to such reactive efforts (Ba et al., 2013; Chen et al., 2009). Recently, Arora et al. (2020) reveal that the stock market reacts more positively to firms that appoint sustainability executives after an adverse incident, which is perceived as damage control. However, consumers appear to be skeptical about it. Consumers perceive a firm's reactive initiatives as a temporary expedient to protect the image of the firm after facing public criticism for the misconduct reported (Groza et al., 2011; Wagner et al., 2009). Studies have also shown that consumers perceive firms' reactive initiatives as selfish and profit-driven, and therefore as insincere (Becker-Olsen et al., 2006; Skarmeas \& Leonidou, 2013; White et al., 2012).

In contrast, proactive ESIs are a firm's ex-ante approaches to preventing any social misconduct among suppliers. Therefore, these initiatives are typically used to reinforce legitimacy, thereby building competitive advantages from the benefits of being a pioneer in the field (Jacobs, 2014; Porter \& Kramer, 2006; Roberts, 2003). Focusing on sourcing, examples of proactive initiatives include new sourcing guidelines for improving the working conditions of foreign suppliers (e.g., Starbucks, see Zachary, 1995) or disclosing a list of suppliers to make the supply chain more transparent (e.g., Wal-Mart, see Banjo, 2013). Contrary to reactive initiatives, investors tend to be skeptical about firms' proactiveness (Arora et al., 2020; Ba et al., 2013). For example, against expectations, the stock market does not value the Bangladesh safety accord and alliance coordinated 
by associated retailers (Jacobs \& Singhal, 2017). On the contrary, consumers perceive firm proactive initiatives as a genuine effort that goes beyond minimum requirements, generating benefits for the whole society. Therefore, in general, consumers react favorably to such firm efforts (Groza et al. 2011; Lamin \& Zaheer, 2012; Trudel \& Cotte, 2009), although some show the opposite result (Wagner et al., 2009).

\section{Economic Effects of ESIs}

While the literature has emphasized the importance of ESIs as a means to ensuring social responsibility in supply chains (Locke \& Romis, 2007; Preuss, 2009; Roberts, 2003), very little is known about whether and how this corporate effort is beneficial to firm value. For instance, Kim et al. (2018) reveal that many prior studies in the field have focused on non-economic consequences of ESIs such as buyer reputation, satisfaction, and relationship performance. This scarcity of studies and evidence on the economic effects of ESIs may come from that the field of ethical sourcing is still in an early stage (Kim et al., 2018), in which conceptual development is the main focus.

To help develop our theoretical arguments for the relationship between ESIs and the value of the firm, we briefly review the literature on stock market reactions to CSR. There is a growing consensus that CSR initiatives overall prompt positive shareholder reactions (e.gFlammer, 2013; Luo \& Bhattacharya, 2006). The proponents of CSR argue that socially responsible practices help firms protect their reputation (Orlitzky et al., 2003), improve operating efficiency through innovation (Porter \& Van der Linde, 1995), and create new market opportunities (Klassen \& McLaughlin, 1996). However, studies also show negative (e.g., Dam \& Petkova, 2014; Hawn et al., 2018; Jacobs, 2014; Lewis and Carlos, 2019), or insignificant (e.g., Arora et al., 2020; Gilley et al., 2000; Mishra \& Modi, 2016) market value effects of CSR. Further, some studies find that the stock market reacts differently to different types of CSR initiatives. For example, Mishra and Modi (2016) find empirical evidence that investors favor CSR efforts that have direct impacts on the firm's value chain and the competitive environment more than community-based CSR initiatives such as charitable giving.

In addition, stock market reactions to CSR tend to vary according to specific firm and environmental characteristics such as external pressure over time (e.g., Flammer, 2013), size of the firm announcing the CSR-related events (e.g., Darnall et al., 2010), and the possibility of financial distress (e.g., Ba et al., 2013; Fama \& French, 1993). Moreover, the timing of when firms engage in CSR initiatives could play an important role in shaping both consumer (Wagner et al., 2009; Yoon et al., 2006) and investor (Hawn et al., 2018;
Janney \& Gove, 2011) reactions. In general, these reactions differ depending on who perceives a firm's CSR initiatives: consumers place a higher value on social performance, while investors favor economic performance the most (Lamin \& Zaheer, 2012).

Regarding ESIs, we find only one study examining the causal relationship between ESIs and firm value. Recently, Jacobs and Singhal (2017) estimate the market value effects of retailers' coordinated responses to the Rana Plaza disaster, namely the "Accord on Fire and Building Safety in Bangladesh" and the "Alliance for Bangladesh Worker Safety." The authors find that both agreements, which are more coordinated, far-reaching, and proactive than predisaster efforts, are not significantly associated with firm market value. Again, we suspect that this counterintuitive result may be due to the absence of the consideration of the contingencies discussed earlier. Therefore, mirroring the developments in the literature, we examine in this paper the shareholder value effects of corporate ESIs and further explore the moderating roles of the types of ESI strategy (i.e., reactive and proactive) and other contextual conditions.

\section{Theory and Hypotheses}

\section{Business Cases for ESIs}

We expect that corporate ESIs create shareholder value for the following reasons. First, ESIs are directly related to the firm's core business and reinforce its value chain. Scholars have argued that CSR can bring economic benefit if it is related to the firm's core business and does not overlap with the efforts of non-profit organizations (Kaul \& Luo, 2018; McWilliams \& Siegel, 2001). In contrast, community-based CSR initiatives such as charitable giving have been suggested to be less beneficial for firm performance (Mishra \& Modi, 2016). By definition, ESIs are the initiatives for making the firm's procurement process more ethical and socially responsible. Since procurement is one of the core activities in the value chain (Porter, 1985), investors or shareholders could recognize ESIs as a type of CSR that reinforces the firm's value chain and potentially benefit both the business and society (Porter \& Kramer, 2006).

Second, ESIs can improve supplier performance. The implementation of ESIs typically involves substantial supplier development and relationship management efforts such as supplier audits, performance monitoring and feedback, supplier employee training, frequent communication and knowledge exchange, and capital investment (Andersen and Skjoett-Larsen, 2009; Blome et al., 2014; Preuss, 2009; Spence \& Bourlakis, 2009). These efforts by the buying firm could improve not only the supplier's environmental or social performance but also its operational performance 
(Blome et al., 2014). For example, ethical sourcing standards and accompanying performance monitoring can induce supplier innovation and improved efficiency (Porter \& Van der Linde, 1995). Quality improvement and cost reduction of suppliers can also be achieved through more efficient use of resources and reduction of wastes (Carter et al., 2000; Fiksel, 1997; Klassen \& McLaughlin, 1996). Supplier performance improvement, in turn, contributes to the buying firm's operational performance (Humphreys et al., 2004; Krause et al., 2000).

Third, ESIs can function as a clear signal that provides psychological benefits to shareholders and other stakeholders (Bhattacharya et al., 2009; Roberts, 2003). ESIs typically include ethical sourcing mandates or supplier codes of conduct to require suppliers to comply with the buying firm's detailed social standards (Roberts, 2003; Jiang, 2009). Although originally directed toward suppliers, these codes of conduct can also provide customers or shareholders with the psychological value that their money is spent or invested for the good cause contributing to the society (Bhattacharya et al., 2009; Preuss, 2009; Roberts, 2003). Social disclosures such as ESIs can also reduce investors' informational uncertainty (Ullmann, 1985) and signal the competence of the management (Alexander \& Buchholz, 1978). Thus, we hypothesize that:

Hypothesis 1 Corporate ESIs have a positive effect on shareholder value.

\section{Reactive versus Proactive ESIs}

We next argue that the magnitude of the positive effects of ESIs on shareholder value could vary depending on whether they are reactive or proactive initiatives. As earlier noted, there are two major research streams for examining the performance impact of CSR. One stream takes the perspective of consumers (Main Street) and the other takes the perspective of investors (Wall Street) (Lamin \& Zaheer, 2012). In general, consumers place a higher value on proactive initiatives than on reactive initiatives as they perceive that proactive CSR initiatives are more future- and stakeholder-oriented (Becker-Olsen et al., 2006; Groza et al., 2011; Porter \& Kramer, 2006). By contrast, investors, whose reactions are likely to be affected by consumer's actual purchasing behavior (Dorobantu et al., 2017; Kim et al., 2019), may respond more positively to reactive ESIs than to proactive ESIs. The rationale for this argument is based on the following two issues.

First of all, the consumers' positive attitudes toward a firm's proactive ESIs do not always reflect their actual reward behavior. For example, although consumers are increasingly interested in ethically sourced products (e.g., fair trade coffee; Argenti, 2004), whether they are willing to pay premiums for such products remains uncertain. Some prior studies show consumers' willingness to pay for ethically produced goods (e.g., Trudel \& Cotte, 2009) while others suggest that price, quality, and brand are still the most determining factors of consumer purchasing decisions (e.g., De Pelsmacker et al., 2005; White et al., 2012). In this sense, the uncertainty caused by this consumer attitude-behavior gap could make it difficult for a firm's proactive initiatives to elicit distinct positive reactions from the stock market.

Relatedly, a firm's proactive initiatives do not always provoke consumers' positive attitudes toward the firm, especially when the firm's statements differ from its actions (Carlos \& Lewis, 2018; Janney \& Gove, 2011; Scheidler et al., 2019). For example, Wagner et al. (2009) find that consumers become more suspicious about a firm's CSR when the firm announces CSR programs before showing socially irresponsible behaviors than when a firm engages in CSR after its socially irresponsible behaviors are exposed. Moreover, Aragón-Correa and Sharma (2003) argue that proactive approaches are based on subjective interpretations of socially responsible issues. Such "egoistic-driven motives" are known to raise consumers' doubts about the effectiveness of the firm's CSR initiatives (Skarmeas \& Leonidou, 2013).

Therefore, we argue that a firm's proactive ESIs can reflect an agency problem. That is, proactively engaging in ESIs may incur unnecessary costs that draw resources from profitable business areas, thus hampering firm performance (Brammer \& Millington, 2008; Davis, 1973; Walley \& Whitehead, 1994). For instance, when Wal-Mart proactively announced stringent ethical and social standards for its Chinese suppliers, the reaction from the stock market was mixed as investors raised questions about operational costs and demand for products (Zimmerman \& Fong, 2008). These potential agency problems associated with proactive ESIs indeed can lower a firm's current and future cash flows. In contrast to proactive ESIs, reactive ESIs have fewer agency problems as they are more focused on directly addressing weaknesses and allocating resources to further improve existing core businesses (Ba et al., 2013; Kang et al., 2016; Kaul \& Luo, 2018). Taken all together, we hypothesize that:

Hypothesis 2 Reactive ESIs have a greater positive effect on shareholder value than proactive ESIs.

\section{Effects of Contextual Factors}

We next investigate specific conditions under which the stock market responds differently to corporate ESIs. As discussed earlier, the causal link between CSR and shareholder value is difficult to generalize, as the relationship outcome can vary largely by contingent situations (Aragón-Correa \& Sharma, 2003). This is especially the case for CSR strategies such as reactive and proactive ESIs. Accordingly, in this 
study, we argue that ESI strategies can only be a source of a competitive edge when they are best aligned with internal and external contextual factors. As set out in detail below, CSR scholars have introduced factors that influence the direct relationship between social initiatives and stock performance: institutional norms, firm visibility and resources, and capital constraints (Ba et al., 2013; Barnea \& Rubin, 2010; Darnall et al., 2010; Hawn et al., 2018). For instance, the larger the firm size, the higher the average cost of implementing CSR, which influences investors' perceptions of future firm performance. Indeed, these factors are the most relevant contingencies with which firms are confronted when pursuing CSR. However, it is still unclear how they interact with reactive or proactive ESI strategies, and in particular how those interactions would elicit different market reactions. Below, we explore initiative timing, firm size, and financial risk as contingencies, and their potential effects on market reaction to a firm's reactive versus proactive ESIs.

\section{Initiative Timing}

In the markets with increasing social awareness like in the United States, investors have been reacting less positively toward CSR over time in the past decades (Flammer, 2013; Jacobs, 2014). As the public has become more socially conscious, investors in more recent periods may consider CSR initiatives as normal activities that most firms perform. Due to this trend, investors' positive reaction to CSR announcements has been decreasing over time (Flammer, 2013). Furthermore, since an increasing number of firms adopt CSR, it has become more difficult for firms to differentiate themselves and achieve competitive advantage by "doing good" to society (Jacobs, 2014). Therefore, albeit some find an opposite trend (e.g., Hawn et al., 2018), it is possible that investors' positive reaction to ESIs has been also decreasing over time.

Extending the literature, we argue that this effect of time could diverge between reactive and proactive initiatives. In times of lower social awareness (i.e., earlier time periods), investors may value a firm's proactive efforts more than reactive ones, as these efforts are generally rewarded by the public and therefore by investors (Flammer, 2013). In times of higher social awareness (i.e., more recent time periods), however, investors may value a firm's reactive efforts more than proactive ones as these efforts are geared directly toward addressing existing weaknesses and therefore create fewer agency problems (Ba et al., 2013; Eccles et al., 2014). In other words, when CSR benefits recede, investors may react less favorably to proactive ESIs with ambiguous impacts on firm core competencies and more agency problems (Kang et al., 2016; Kaul \& Luo, 2018). This reasoning leads us to consider initiative timing as a moderator for the stock market reaction to reactive versus proactive ESIs. Therefore, we offer that:

Hypothesis 3 The shareholder value effect of reactive ESIs compared to proactive ESIs is greater for more recent ESIs than earlier ESIs.

\section{Firm Size}

Firm size matters to the adoption of a firm's ESI strategy. Conventional wisdom is that larger firms are more visible to the public. Also, they generally have more resources in responding to external social pressures resulting from the public (Darnall et al., 2010; Gilley et al., 2000). This makes larger firms engage in proactive social initiatives. However, organizational (control and coordination) costs for substantive ESIs increase with firm size (BaumannPauly et al., 2013; Wickert et al., 2016). This gives larger firms cost advantages to engage in proactive but symbolic or political ESIs (Shevchenko et al., 2016). That is, larger firms talk about social problems in sourcing but are less motivated to bring that talk into action, which can backfire like perceived corporate hypocrisy (Carlos \& Lewis, 2018; Wagner et al., 2009; Yoon et al., 2006). In this sense, for larger firms, investors may value proactive ESIs less than reactive ESIs, which are more subject to either high organizational costs or potential public backlash.

By contrast, smaller firms are considered as less advanced in organizing proactive CSR mainly due to their low visibility and lack of resources. However, this assumption has often been questioned in the literature. In general, smaller firms have more flexibility in implementing social initiatives (Aragón-Correa et al., 2008; Gilley et al., 2000) and are often considered more innovative than larger firms for responding to external social pressure (Darnall et al., 2010). Moreover, smaller firms tend to have more cost advantages to engage in substantive ESIs because of their lower levels of bureaucracy, complexity, and inertia (Baumann-Pauly et al., 2013; Gilley et al., 2000; Wickert et al., 2016). In that sense, smaller firms are motivated to spend more on proactive CSR for actual social problems in the sourcing context (Darnall et al., 2010), making those firm efforts more genuine with less potential for being perceived as hypocritical (Scheidler et al., 2019; Wagner et al., 2009). Given the discussion, for smaller firms, investors may value proactive ESIs more than reactive ESIs. Taken together, we hypothesize that:

Hypothesis 4 The shareholder value effect of reactive ESIs compared to proactive ESIs is greater for larger firms than smaller firms. 


\section{Financial Risk}

Although debtholders do not have voting rights as common stockholders, they are influential stakeholders to firms. For example, debt-servicing obligations suggest that debtholders can strictly monitor a firm's debt funds spending (Artiach et al., 2010). Debtholders can also influence a firm's decisions by replacing key decision-makers of the firm (Gilson, 1990). Studies have shown that such financial risk associated with high debt ratios influences firm resource allocation and investment decisions in a way that prioritizes debtholder concerns (Barnea \& Rubin, 2010; Sadovnikova \& Pujari, 2017).

From the perspective of the investors, a firm's leverage could influence the valuation of the firm because it is associated with tax advantage as well as default risk (Kraus \& Litzenberger, 1973; Ruland \& Zhou, 2005). As noted above, firms with excessive levels of leverage typically have limited resources to make new investments (Artiach et al., 2010; Barnea \& Rubin, 2010). Therefore, investors expect highly leveraged firms to keep the current financial position while investing mainly in existing or potentially profitable businesses (Ba et al., 2013; Eccles et al., 2014; Kang et al., 2016). Under this condition, the stock market may react more favorably to reactive ESIs than proactive ESIs as reactive ESIs take more targeted approaches to address specific, urgent problems.

Conversely, firms with low leverage ratios tend to have slack resources and could be more flexible in terms of making new investment decisions (Ba et al., 2013; Barnea \& Rubin, 2010; Sadovnikova \& Pujari, 2017). Studies suggest that slack resources allow firms to engage in more proactive and substantive CSR initiatives (Darnall et al., 2010; Wickert et al., 2016). Engaging in proactive CSR could potentially enhance consumer attitudes (Barone et al., 2000; Berens et al., 2005) and employment intent (Kim \& Choi, 2012; Scheidler et al. 2019). Therefore, in stark contrast to above, the stock market may become more open to proactive ESIs than reactive ESIs, if the firms implement the initiatives with lower financial risk. This leads us to the final hypothesis:

Hypothesis 5 The shareholder value effect of reactive ESIs compared to proactive ESIs is greater for firms with higher financial risks than firms with lower financial risks.

\section{Methodology}

\section{Data Collection and Sample}

Our data consists of two parts. First, we searched the Wall Street Journal (WSJ) to collect announcements of firm ESIs made from 1989 to 2014. The keywords used in the search were: supplier, contractor, sourcing, procurement, ethic*, social*, responsib*, factory, plant, audit, inspection, monitor*, standard, guideline, codes, compliance, and other relevant terms. Using combinations of the above keywords, our iterative search generated 245 initial announcements that pertain only to publicly traded U.S. firms' ESIs. Then, we excluded firms that did not have sufficient stock price information, and that implemented ESIs but with potentially confounding events (e.g., mergers, earnings announcements) by searching the WSJ for our sample firms during the event window.

Applying these selection criteria, our final sample consists of 159 firm-ESIs (from 118 announcements), which is listed fully in Appendix. Some examples of proactive ESIs are: "Starbucks adopts guidelines to improve conditions for foreign coffee workers" (Zachary, 1995); "Philips Electronics NV: Suppliers will be required to observe labor standards" (WSJ, 2004); "Chinese suppliers face new Wal-Mart mandates" (Zimmerman \& Fong, 2008); "Wal-Mart, Gap press for safety in Bangladesh" (Banjo, 2013). Examples of reactive ESIs include: "Nike cancels pacts with Indonesian plants over wage policies" (WSJ, 1997); "McDonald's, Mattel dispute allegations about Chinese plant" (Batson, 2006); "Apple, H-P to examine Asian supplier after string of deaths at factory" (Dean \& Tsai, 2010); "Wal-Mart boosts its vendor compliance in China following criticism" (Burkitt, 2014).

Two coders were involved to assess each announcement and determine whether the ESI is proactive or reactive. The inter-rater reliability was over $95 \%$, indicating a near-perfect agreement (Cohen, 1960). The two coders further resolved disagreements through discussions. Of the 159 firm-ESIs, we classified 57 cases as proactive, and 102 cases as reactive initiatives. The fact that reactive ESIs are more frequently observed supports the notion that reactive ESIs are 'default' responses for most firms when facing supplier social irresponsibility. Our sample size is comparable to those of earlier WSJ-based event studies (e.g., Arora et al., 2020; Flammer, 2013; Gilley et al., 2000).

The second part of data consists of the sample firms' stock price and other financial information. We collected the sample firm's daily stock price data from the Center for Research in Security Prices (CRSP) database. Other financial information such as market value of equity (mean $=\$ 87,35 \mathrm{~B}$, $\mathrm{SD}=\$ 89,64 \mathrm{~B})$, total assets (mean $=\$ 88,59 \mathrm{~B}, \mathrm{SD}=\$ 91,74 \mathrm{~B})$, sales $($ mean $=\$ 114,13 \mathrm{~B}, \mathrm{SD}=\$ 138,50 \mathrm{~B})$, net income (mean $=\$ 5,46 \mathrm{~B}, \mathrm{SD}=\$ 6,89 \mathrm{~B})$, and long-term debt (mean $=\$ 15,83 \mathrm{~B}, \mathrm{SD}=\$ 22,22 \mathrm{~B}$ ) was obtained from the Compustat database. We also obtained from Compustat the information on two-digit standard industrial classification codes that we used to group the sample firms into five industry types: mining and construction (6.29\%) manufacturing (53.46\%), 
transportation and public utilities $(0.63 \%)$, wholesale and retail trade $(38.99 \%)$, and services $(0.63 \%)$.

\section{Data Analysis}

We test our hypotheses using an event study methodology. This method has been widely used to examine stock market reactions to firm events like ESIs. The usefulness of event studies comes from the Efficient Market Hypothesis which suggests that investor reactions to the firm events are reflected immediately in stock prices (Fama, 1970). Furthermore, event studies are considered one of the more rigorous approaches to measuring the economic effects of corporate policy decisions (Kothari \& Warner, 2007). Thus, the event study methodology is useful for estimating the economic effects of corporate ESIs. We achieve this by observing the behavior of stock market prices over relatively short periods when the events occurred.

In this study, we estimate abnormal stock returns using the Fama-French (FF) four-factor model (Carhart, 1997; Fama \& French, 1993). This is a benchmark model that augments the classic market factor (cf. Brown \& Warner, 1985) with three other risk factors specified as:

$R_{i t}=\alpha_{i}+R_{f t}+\beta_{i}\left[R_{m t}-R_{f t}\right]+s_{i} S M B_{t}+h_{i} H M L_{t}+u_{i} U M D_{t}+\varepsilon_{i t}$,

where $R_{i t}$ is the stock return on day $t$ of firm $i, R_{f t}$ is the riskfree return on day $t, R_{m t}$ is the stock return of the market index on day $t, S M B_{t}$ is the small-minus-big size portfolio return on day $t, H M L_{t}$ is the high-minus-low book-to-market portfolio return on day $t, U M D_{t}$ is the up-minus-down momentum (past performance) portfolio return on day $t$, and $\alpha_{i}$ and $\varepsilon_{i t}$ are the intercept and error term, respectively. In robustness checks, we also show whether our event study results are robust to alternative models such as the market model (Brown \& Warner, 1985).

The abnormal return (AR) on day $t$ of firm $i$ is the difference between the actual $\left(R_{i t}\right)$ and expected $\left(E\left(R_{i t}\right)\right)$ return:

$A R_{i t}=R_{i t}-E\left(R_{i t}\right)$

To compute the expected return, we estimate the model parameters, $\widehat{a}_{i}, \widehat{\beta}_{i}, \widehat{s}_{i}, \widehat{h}_{i}$, and $\widehat{u}_{i}$, using ordinary least squares (OLS) regression over the estimation period of -210 through - 11 (200 trading days). Then, the mean AR is calculated by:

$\overline{A R}_{i t}=\sum_{i=1}^{N} R_{i t} / N$

where $N$ is all events in our sample. Finally, the ARs are cumulative (CARs) over a specific time window $\left[t_{l}, t_{2}\right]$ :

$C A R\left[t_{1}, t_{2}\right]=\sum_{t=t 1}^{t 2} A R_{i t}$

In order to avoid estimation bias, it is crucial to choose an appropriate event window (McWilliams \& Siegel, 1997).
Following common practice (e.g., Jacobs, 2014; Kim et al., 2019), we use the announcement day (i.e., Day 0) and the day before the announcement (i.e., Day - 1). We use this two-day event window as our main specification, given that information about firms' ESI events can be leaked to the press (therefore to the market) on the day before the announcement (MacKinlay, 1997).

To estimate the moderating effects of contextual factors, we developed the following OLS regression model in hierarchical order:

$C A R=\alpha_{0}+\beta_{1-4} X+\gamma_{5-8} M+\delta_{9-11} T+\varepsilon$,

where the dependent variable is the 2-day $[-1,0]$ CAR (\%) for firm $i$. Specifically, $X$ is a vector of industry-type control variables $\left(\beta_{1-4}\right)$, which was entered as a block in Model 1 . This is followed by $M$, the four main variables i.e., ESI strategy $\left(\gamma_{5}\right)$, initiative timing $\left(\gamma_{6}\right)$, firm size $\left(\gamma_{7}\right)$, and financial risk $\left(\gamma_{8}\right)$, entered in Model 2. $T$, which are the three interaction terms of ESI strategy with the other main variables, initiative timing $\left(\delta_{9}\right)$, firm size $\left(\delta_{10}\right)$, and financial risk $\left(\delta_{11}\right)$ was then entered in Model 3.

Following common practice, we measure firm ESI strategies as a binary variable (e.g., Chen et al., 2009), in which a value of 1 represents reactive initiatives and 0 proactive initiatives, and firm size by the natural logarithm of total assets (e.g., Ba et al., 2013). We use debt ratio as a proxy for financial risk, often calculated as long-term debts divided by total assets (e.g., Artiach et al., 2010; Barnea \& Rubin, 2010). Recently, Kim et al. (2018) reveal that firms' ethical sourcing is now being in the spotlight, especially after 1998 when Nike's child labor scandals brought intense criticisms from consumers (also cf. Nisen, 2013; Zadek, 2004). Building on this, we consider 1998 as the inflection point of differentiated market reactions to ESIs and measure the timing of ESIs as a binary variable assuming a value of 1 if the firm's ESI is made on or after 1998 (i.e., recent time) and 0 otherwise. In robustness checks, we also consider alternative measures such as 2006 as the second inflection point (Kim et al., 2018) and linear time. Finally, we control for industry effects by using a set of dummy variables, with manufacturing as the referent category. Table 1 presents the summary statistics of our main variables for regression analysis.

\section{Empirical Results}

\section{Hypothesis Testing}

Figure 1 presents the event study results. For each day, we report the mean (solid line) and median (dotted line) AR (\%) and the corresponding significance test results. For Day 0 , the mean (median) AR is $0.49 \%(0.34 \%)$, with the 
Table 1 Descriptive statistics and correlation matrix

\begin{tabular}{lrlrlrl}
\hline Variable & Mean & SD & 1 & 2 & 3 & 4 \\
\hline 1. CAR [- 1, 0] (\%) & 1.021 & 2.184 & & & & \\
2. Reactive ESI & 0.642 & 0.481 & 0.098 & & & \\
3. Recent time & 0.868 & 0.334 & 0.044 & 0.035 & & \\
4. Firm size & 10.506 & 1.607 & -0.077 & 0.034 & $0.303^{* * *}$ & \\
5. Financial risk & 0.174 & 0.111 & $0.200^{*}$ & $0.143^{+}$ & -0.105 & 0.020 \\
\hline
\end{tabular}

$n=157$ (two observations were dropped due to missing data)

${ }^{+} p<0.10 ; * p<0.05, * * * p<0.001$

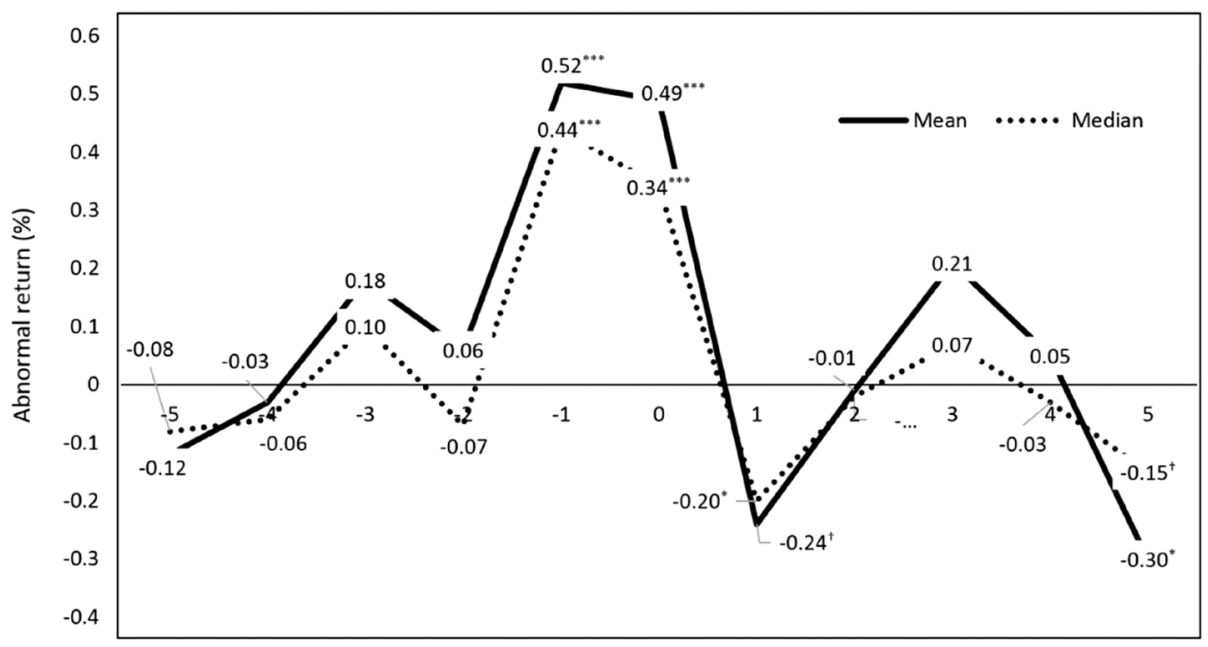

Notes: $n=159$; $t$-tests are used for mean ARs; Wilcoxon signed-rank $Z$ tests are used for median ARs; ${ }^{+} p<0.10,{ }^{*} p<0.05,{ }^{* * *} p<0.001$.
Fig. 1 AR ( -5 through 5$)$ for corporate ESIs
$64.78 \%$ positive reactions. For Day -1 , the mean (median) AR is $0.52 \%(0.44 \%)$, with the $61.64 \%$ positive reactions. Accordingly, over the two-day event window [Days - 1, 0], we find a positive mean (median) CAR of $1.01 \%(0.78 \%)$, which is significant at the $0.1 \%$ level. For the event window, $114(71.70 \%)$ out of 159 ESIs are positive, which is also significant at the $0.1 \%$ level. Overall, these results provide strong support for H1. Figure 1 also shows that the mean (median) ARs for the other event days are trivial and statistically insignificant, supporting our choice of the two-day specification.

Table 2 documents the results of our event study analysis for reactive versus proactive ESIs. The CARs for both ESI strategies are positive and significant. Specifically, we find that the mean (median) CAR is $1.15 \%(0.87 \%)$ for reactive ESIs and $0.75 \%(0.58 \%)$ for proactive ESIs. Yet, the significance tests for the difference in the means (medians) of CARs for the ESI strategies are insignificant. This means that there is no significant difference in stock market reactions to reactive and proactive ESIs. We reveal the same result in regression analyses. As shown in Table 3, the coefficients of reactive ESIs (against proactive ESIs) are positive but not statistically significant. This leads us to reject our
Table 2 CAR $[-1,0]$ for reactive and proactive ESIs

\begin{tabular}{llll}
\hline & Reactive & Proactive & Difference \\
\hline Mean CAR (\%) & $1.15^{* * *}$ & $0.75^{*}$ & -0.40 \\
$t$-statistic & 5.47 & 2.49 & -1.12 \\
Median CAR (\%) $^{*}$ & $0.87^{* * *}$ & $0.58^{*}$ & -0.29 \\
Z-statistic $^{\mathrm{a}}$ & 4.01 & 2.53 & -1.35 \\
CAR Positive (\%) $^{*}$ & $77.45^{* * *}$ & $61.40^{+}$ & \\
$Z$-statistic & 5.61 & 1.84 & \\
$n$ & 102 & 57 & \\
\hline
\end{tabular}

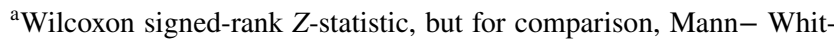
ney tests are used; ${ }^{\text {b }}$ generalized sign $Z$-statistic

${ }^{+} p<0.10, * p<0.05, * * * p<0.001$

$\mathrm{H} 2$. However, we find some support for $\mathrm{H} 2$ in the alternative models and long-run analyses that we present in the following sub-section.

Table 3 presents the results of our regression analysis. Two cases were dropped due to missing data. As shown in Model 3, we find the positive effects of recent time $(\beta=0.173, p<0.10)$ and financial risk $(\beta=0.222, p<0.05)$ on the two-day CAR. This indicates that overall, the more 
Table 3 Regression analysis of CAR $[-1,0]$

\begin{tabular}{|c|c|c|c|c|}
\hline Variable entered & & Model 1 & Model 2 & Model 3 \\
\hline Constant & & $0.895 * * *(3.764)$ & $1.186 * * *(4.636)$ & $1.086 * * *(4.235)$ \\
\hline Mining and construction ${ }^{\mathrm{a}}$ & & $0.143^{+}(1.746)$ & $0.066(0.758)$ & $0.101(1.136)$ \\
\hline Transportation and public ${ }^{\mathrm{a}}$ & & $-0.010(-0.127)$ & $-0.031(-0.389)$ & $-0.034(-0.429)$ \\
\hline Wholesale and retail & & $0.028(0.341)$ & $-0.118(-1.223)$ & $-0.093(-0.977)$ \\
\hline Services $^{\mathrm{a}}$ & & $-0.004(-0.045)$ & $0.004(0.048)$ & $0.002(0.022)$ \\
\hline Reactive ESI & & & $0.064(0.800)$ & $0.076(0.956)$ \\
\hline Recent time & & & $0.143(1.600)$ & $0.173^{+}(1.954)$ \\
\hline Firm size & & & $-0.131(-1.474)$ & $-0.109(-1.214)$ \\
\hline Financial risk & & & $0.238 *(2.567)$ & $0.222 *(2.426)$ \\
\hline \multicolumn{5}{|l|}{ Reactive ESI $\times$} \\
\hline Recent time & $\mathrm{H} 3$ & & & $0.043(0.492)$ \\
\hline Firm size & $\mathrm{H} 4$ & & & $0.192 *(2.240)$ \\
\hline Financial risk & H5 & & & $0.066(0.830)$ \\
\hline$R^{2}(\%)$ & & 1.99 & 8.01 & 12.61 \\
\hline$R^{2}$ change $(\%)$ & & & 6.01 & 4.61 \\
\hline$F$ change & & & $2.418^{+}$ & $2.548^{+}$ \\
\hline$F$-statistic & & 0.773 & 1.610 & $1.903 *$ \\
\hline
\end{tabular}

$n=157$; standardized coefficients are reported; $t$-statistics are shown in parentheses; ${ }^{\text {areferent }}$ category is manufacturing; ${ }^{\mathrm{b}} 1=$ reactive

${ }^{+} p<0.10 ; * p<0.05, * * * p<0.001$ recent (after 1998) a firm's ESI is made, or the higher a firm's debt ratio, the greater the positive stock market reaction. However, such interpretation requires caution because, as we noted earlier, the direction and magnitude of the CAR can vary by the interplay with ESI strategies. Accordingly, we tested the interaction effects of reactive (proactive) ESIs with initiative timing, firm size, and financial risk on stock market reactions. As a result, we find the positive shareholder value effect of reactive-firm size ( $\beta=0.192$, $p<0.05$ ). Results from the follow-up simple slope test for the interaction are shown in Fig. 2, indicating that the stock performance difference of proactive ESIs over reactive ESIs is greater for smaller firms than for larger firms. The test results also show that for larger firms, investors value reactive ESIs more than proactive ESIs.

To verify our results, we tested the regression model for each reactive and proactive sample. The results are presented in Table 4. Consistent with the results above, we find the shareholder value effect of firm size for proactive ESIs is negative and significant $(\beta=-0.377, p<0.05)$. Our comparison test using an $F$-test also shows a significant difference in the coefficients between the models $(F=6.025)$. This means that the magnitude of CAR associated with proactive (over reactive) ESIs is greater for smaller firms. On the contrary, no significant effects on shareholder value are found regarding initiative timing (recent time) and financial risk; but for reactive ESIs, we find the positive effect of initiative timing $(\beta=0.252, p<0.05)$ and financial risk $(\beta=0.368, p<0.01)$ on the 2-day CAR. However, the $F$-statistics for both do not

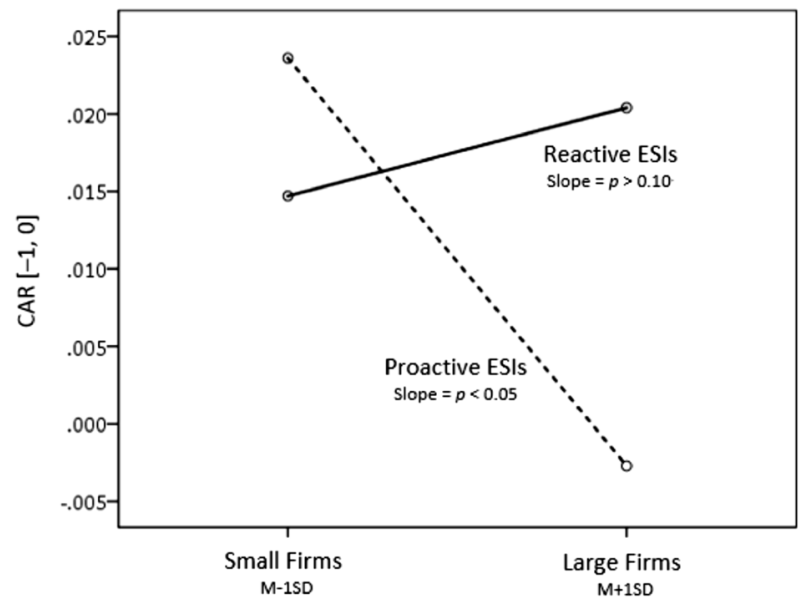

Fig. 2 Interaction of reactive (proactive) ESI with firm size

support a significant difference between the models. Thus, we find strong support for $\mathrm{H} 4$, but no support for $\mathrm{H} 3$ and $\mathrm{H} 5$.

\section{Robustness Checks}

\section{Cross-Sectional Correlation}

In our sample, there are few cases that multiple firms are involved in a specific ESI or that several ESIs cluster around certain dates. For example, after the Rana Plaza disaster, North American retailers such as Wal-Mart, J.C. 
Table 4 Regression analysis of CAR $[-1,0]$ for reactive and proactive ESIs

\begin{tabular}{|c|c|c|c|c|c|}
\hline \multicolumn{2}{|l|}{ Variable entered } & \multirow{2}{*}{$\begin{array}{l}\text { Reactive } \\
1.561 * * *(5.330)\end{array}$} & \multirow{2}{*}{$\begin{array}{l}\text { Proactive }^{\mathrm{b}} \\
0.763^{*}(2.554)\end{array}$} & \multicolumn{2}{|c|}{ Difference $^{c}$} \\
\hline Constant & & & & & \\
\hline Mining and construction ${ }^{\mathrm{a}}$ & & $0.016(0.155)$ & & & \\
\hline Transportation and public utilities ${ }^{\mathrm{a}}$ & & $-0.062(-0.635)$ & & & \\
\hline Wholesale and retail $^{\mathrm{a}}$ & & $-0.292 *(-2.463)$ & & & \\
\hline Services $^{\mathrm{a}}$ & & $-0.003(-0.029)$ & & & \\
\hline Recent time & H3 & $0.252 *(2.327)$ & $0.115(0.778)$ & No & (1.562) \\
\hline Firm size & $\mathrm{H} 4$ & $-0.039(-0.365)$ & $-0.377 *(-2.551)$ & Yes* & $(6.025)$ \\
\hline Financial risk & H5 & $0.368 * *(3.303)$ & $0.125(0.967)$ & No & $(0.221)$ \\
\hline Observations & & 101 & 56 & & \\
\hline$R^{2}(\%)$ & & 13.84 & 13.01 & & \\
\hline$F$-statistic & & $2.134 *$ & $2.592^{+}$ & & \\
\hline
\end{tabular}

Standardized coefficients are reported; $t$-statistics ( $F$-statistics for comparison) are shown in parentheses; ${ }^{a}$ referent category is manufacturing; ${ }^{b}$ due to the reduced sample size, industry controls were not included in the model; ' each comparison test was conducted using an $F$-test, without industry controls

${ }^{+} p<0.10, * p<0.05, * * p<0.01, * * * p<0.001$
Penny, and Sears Holdings decided to craft a safety plan for improving working conditions at Bangladesh factories (Banjo et al. 2013). This clustering may violate the assumption of standard event study methodology that the sample should consist of independent events. To ensure that our results are not driven by this potential cross-sectional correlation problem, we follow Brown and Warner (1985) (also cf. Flammer, 2013; Hawn et al., 2018) and re-estimate the mean (median) CARs using the time-series standard deviation (also known as "crude dependence adjustment") test. In non-tabulated results, we find a significant $(p<0.001)$ mean (median) CAR of $1.01 \%(0.78 \%)$, indicating that our results shown in Table 2 are robust to the potential cross-sectional correlation of stock returns. This robustness is also the case for reactive and proactive ESIs.

\section{Testing with Alternative Models}

To ensure that our event study results are robust to other alternative models, we re-estimate the mean (median) CAR using the FF three-factor model (Fama \& French, 1993) and the market model (Brown \& Warner, 1985). Our test results show very similar results. For the FF three-factor model, we find a significant mean (median) CAR of $1.10 \%(0.91 \%)$ with $74.84 \%$ positive reactions. For the market model, we find a significant mean (median) CAR of $1.12 \%(0.81 \%)$ with $76.10 \%$ positive reactions. Looking into ESI strategies, we find CARs very similar to the ones from the main model. One notable result is the significant difference in the medians of CARs between reactive and proactive ESIs (H2), albeit marginally. The results are summarized in Table 5.

We further check whether our regression analysis results are robust to alternative measures (see Table 6). We use 2006 as the second inflection point (Kim et al., 2018) and linear time as alternative measures of the time variable. We also use sales and the number of employees as alternative measures of the size variable. Finally, we use FF3and market-based two-day CARs as alternative measures of the dependent variable. We tested the regression models in hierarchical order; but for brevity, we only present the full model results (equivalent to Model 3 in Table 3). As shown in Table 6, the results with the alternative measures are very similar to the main results. One notable exception is that the market value effect of the reactive-size interaction becomes insignificant when using the number of employees as a proxy for firm size. For the other alternatives, we also performed a simple slope test and separate regression analyses for each reactive and proactive sample. The results are very similar to those shown in Fig. 2 and Table 4. Overall, these results show the robustness of our main regression results.

\section{Dealing with Self-selection Bias}

The implementation of reactive or proactive ESIs is not a random process. Rather, this decision can be affected by a number of additional factors such as a firm's prior experience, which influence the outcomes of the ESI strategy. To check and correct for such a potential self-selection bias and resulting endogeneity concerns, we follow prior studies (e.g., Chen et al., 2009; Kim et al., 2019) and use the two-stage Heckman procedure (Heckman, 1979). In the first stage, we use a probit model (Log-likelihood $=-96.96, n=155)$ on the selection between reactive and proactive ESIs with the following variables: industry type, initiative timing, firm size, financial risk, ROA (operating income divided by total assets), firm age (the number of years since Compustat listing), capital intensity (capital expenditure to the number of employees), and 
Table 5 CAR $[-1,0]$ for ESIs using alternative models

\begin{tabular}{lllll}
\hline & All samples & Sub: reactive & Sub: proactive & Sub: difference \\
\hline Alternative: FF3 & & & & \\
Mean CAR (\%) & $1.10^{* * *}$ & $1.31^{* * *}$ & $0.72 *$ & -0.59 \\
$t$-statistic & 6.34 & 6.13 & 2.47 & -1.65 \\
Median CAR (\%) & $0.91 * * *$ & $1.02 * * *$ & $0.59 * *$ & $-0.43^{+}$ \\
$Z$-statistic & 6.55 & 6.16 & 2.65 & -1.84 \\
$n$ & 159 & 102 & 57 & \\
Alternative: market & & & & -0.46 \\
Mean CAR (\%) & $1.12^{* * * *}$ & $1.28 * * *$ & $0.82^{* *}$ & -1.29 \\
$t$-statistic & 6.56 & 6.13 & 2.82 & $-0.33^{+}$ \\
Median CAR (\%) & $0.81 * * *$ & $0.92 * * *$ & $0.59 * *$ & -1.71 \\
$Z$-statistic & 6.55 & 6.01 & 2.85 & \\
$n$ & 159 & 102 & 57 & \\
\hline
\end{tabular}

${ }^{a}$ Wilcoxon signed-rank $Z$-statistic, but for comparison, Mann-Whitney tests are used

${ }^{+} p<0.10,{ }^{*} p<0.05, * * * p<0.001$ prior experience ( 1 if the announcing firm had a previous ESI and 0 otherwise). Based on the estimates, we generate the inverse Mills ratio $(\lambda)$. In the next stage, we estimate OLS regressions of CAR $[-1,0]$ for both reactive and proactive models, while including $\lambda$ as an additional variable. In this process, we first exclude ROA and then the other additional factors (firm age, capital intensity, and prior experience) sequentially. Non-tabulated results show the insignificant effect of the self-selection bias indicator (i.e., $\lambda$ ) for all estimated models. This indicates that our main results provide an unbiased estimate of the economic effects of firm ESIs in terms of endogeneity that exists in self-selected samples.

\section{Supplementary Analysis}

ESIs, particularly proactive ESIs can take time to be effective (Eccles et al., 2014; Zadek, 2004). Hence, we examine stock market reactions to corporate ESIs over a longer time span. To investigate the post-announcement effect of ESIs, we estimate CARs over a 120-day period (6 months). However, estimating CARs over a longer time span could be sensitive to confounding effects (McWilliams \& Siegel, 1997). To deal with the specification issues caused by volatility in the long term, we follow prior studies (e.g., Capelle-Blancard \& Laguna, 2010; Hendricks et al., 2015, 2020; Kothari \& Warner, 2007) and perform a sub-group analysis of ESI strategies. The results are presented in Table 7 . Within a month (1 to 20), CARs remain negative and somewhat significant but are driven mainly by reactive ESIs. After that period, however, CARs turn to be positive and become stronger in their magnitude particularly for the period of 5-6 months (1 to 100-120). Interestingly, only reactive ESIs drive the overall shareholder value effect. In sum, we find significant post-announcement CARs for reactive ESIs but not for proactive ESIs, albeit no difference in magnitude between the sub-groups.

On top of that, we estimate the long-term operating performance of firm ESIs. Two reasons are: first, we verify the long-term shareholder value effects of ESIs above, which can be subject to high volatility in a longer-term estimation (Kothari \& Warner, 2007); second, we examine whether ESIs, particularly proactive ESIs generate operating performance, which can be a proxy for consumer reaction (i.e., Main Street). Following common practice, we measure ROA for operating performance (ROS as an alternative). Specifically, we compute abnormal ROA changes over the four years ( -1 through 2$)$ using the approach outlined by Barber and Lyon (1996):

$$
\text { AbnormalROA }_{i, t+j}=P_{i, t+j}-E\left(P_{i, t+j}\right),
$$

where $P_{i}$ is the actual ROA $i, E\left(P_{i}\right)$ is the expected ROA of firm $i$ in time $t+j$. The expected ROA means the ROA that the sample firm would gain if the ESI had not been initiated. Given that outliers can affect mean values so strongly (Barber \& Lyon, 1996), the expected ROA is calculated as the actual ROA of sample firms in time $t$ plus the median change in ROA of benchmark firms. We define the base year as -2 , in which a sample firm was free from ESI effects, particularly from proactive ESIs.

Benchmark firms are best determined by matching on prior performance and industry (Barber \& Lyon, 1996). Following the approach, for each sample firm, we first created a benchmark group by identifying all firms (in Compustat) that have the same two-digit SCI code as that of the sample firm, and whose ROAs in the base year were within $90-110 \%$ of the sample firm's ROA. If no firms were identified, then we tried to match each ROA based on the same one-digit SIC code. If no firms were identified again, then 


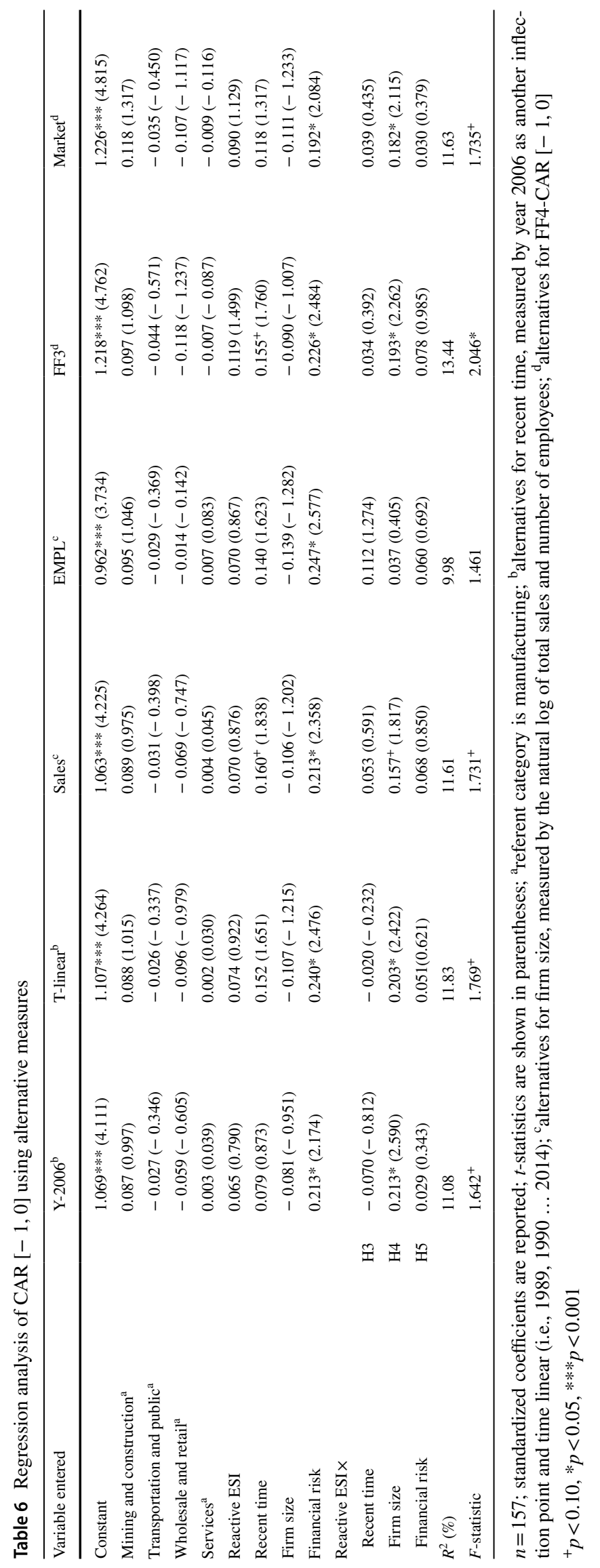


we attempted to match each ROA regardless of the SIC code. Because we were interested in estimating the operating performance of ESIs, we excluded firms that also adopted ESIs in the time frame studied from the benchmark group. As a result, on average, each sample firm matched with a group of 11.99 benchmark firms. The vast majority of benchmark firms were identified in the first procedure. Over $70 \%$ of benchmark groups had five or more firms, and only 17 sample firms were matched with single benchmark firms.

The analysis results are presented in Table 8. To avoid potential confounding effects, we excluded sample firms with the ESIs subsequently made within the four-year period. To control for outliers, which is crucial for accounting-based measures (Barber \& Lyon, 1996), we trimmed our sample at $2.5 \%$ each tail. Both reduced our sample size to $68-75$. Our first result is that abnormal changes in ROA on the base year $(-2$ to -1$)$ are insignificant for all sample groups, indicating no pre-event bias. That is, our sample and benchmark firms did not differ significantly in ROA changes during the year before the implementation of ESI. Yet, we observe a significant difference in ROA changes afterward. We find that sample firms improved their ROA significantly more than benchmark firms around and after the ESI event. Interestingly, these are driven mainly by reactive ESIs. For proactive ESIs, there are no significant differences in ROA changes between sample and benchmark firms. Compared to proactive ESIs, sample firms that implemented ESIs reactively seem to obtain the benefit immediately (years -1 to 0 ) and continuously over the post-implementation periods (years 0 to 1,1 to 2 , and 0 to 2 ). Even we find a significant difference in ROA changes between sample firms' reactive and proactive ESIs (i.e., "sub-difference" in Table 8) for some later periods (years 1 to 2,0 to 2 , and -2 to 2 ). These results are robust if, instead of ROA, we use ROS as an alternative measure of operating performance. Overall, the above findings provide some support for our $\mathrm{H} 2$.

\section{Discussion}

\section{Implications for Research}

ESIs can have wide-ranging effects on businesses and society alike as they are initiated based on the expectations of stakeholders across supply chains. Focusing on this important subset of CSR initiatives, we extend the literature on the economic consequences of CSR by presenting ESIs as an economically viable CSR option. Specifically, our findings suggest that overall, the stock market reacts positively to ESIs. This finding and our theoretical argument for the economic benefits of ESIs are aligned with the concept of "creating shared value" suggested by Porter and Kramer (2006). In summary, ESIs can directly reinforce buying firms' value chains by improving supplier performance through extensive supplier development and relationship management activities (Andersen and Skjoett-Larsen, 2009; Preuss, 2009; Spence \& Bourlakis, 2009; Blome et al., 2014). This noteworthy aspect calls for further attention from CSR researchers in the supply chain context to ESIs.

Focusing on the economic effects of reactive versus proactive ESIs, our findings support the potential agency hazards of proactive ESIs (Kang et al., 2016; Kaul \& Luo, 2018; Mishra \& Modi, 2016), to some extent. Our event study analysis using the FF four-factor model does not support our proposition that reactive ESIs elicit a more positive stock market reaction than proactive ESIs. However, for the alternative models such as the FF three-factor model and the market model, we find a marginally significant effect on the difference of median CARs between reactive and proactive ESIs. This significant difference is particularly the case for the long-term operating effects of ESIs. As earlier discussed, during the post-implementation periods, firms with reactive ESIs experience significantly greater benefits than firms with proactive ESIs in operating performance measured by abnormal changes in ROA compared to benchmark firms.
Table 7 Mean and median CAR (\%) following ESI announcements

\begin{tabular}{|c|c|c|c|c|c|c|c|c|}
\hline \multirow[t]{2}{*}{ Event day } & \multicolumn{2}{|c|}{ All samples } & \multicolumn{2}{|c|}{ Sub: reactive } & \multicolumn{2}{|c|}{ Sub: proactive } & \multicolumn{2}{|c|}{ Sub-difference } \\
\hline & Mean & Median & Mean & Median & Mean & Median & Mean & Median \\
\hline 1 to 10 & $-0.84 *$ & -0.13 & $-0.91^{+}$ & -0.45 & -0.72 & 0.55 & -0.19 & -1.00 \\
\hline 1 to 20 & -0.05 & 0.03 & -0.33 & -0.03 & 0.43 & 0.13 & -0.76 & -0.16 \\
\hline 1 to 40 & 0.51 & -0.30 & 0.07 & -0.83 & 1.30 & 0.29 & -1.23 & -1.12 \\
\hline 1 to 60 & 0.90 & 0.38 & 0.75 & -0.14 & 1.17 & 1.68 & -0.42 & -1.82 \\
\hline 1 to 80 & 1.92 & 0.91 & 1.71 & 0.88 & 2.31 & 1.59 & -0.60 & -0.71 \\
\hline 1 to 100 & $3.87 *$ & $3.65^{*}$ & $4.12 *$ & $4.44 *$ & 3.43 & 1.75 & 0.69 & 2.69 \\
\hline 1 to 120 & $5.32 * *$ & $2.86^{*}$ & $5.15^{*}$ & $2.90 *$ & $5.62^{+}$ & 1.79 & -0.47 & 1.11 \\
\hline
\end{tabular}

$n=159$ (102 for reactive and 57 for proactive sample); $t$-statistic for mean and its comparison, Wilcoxon signed-rank $Z$-statistic for median, and Mann-Whitney $Z$-statistic for its comparison

${ }^{+} p<0.10, * p<0.05, * * p<0.01$ 
Table 8 Annual abnormal changes (\%) in ROA for year -2 to year 2

\begin{tabular}{|c|c|c|c|c|c|c|c|}
\hline \multirow[t]{2}{*}{ Year-to-year } & \multicolumn{2}{|c|}{ All samples } & \multicolumn{2}{|c|}{ Sub: reactive } & \multicolumn{2}{|c|}{ Sub: proactive } & \multirow{2}{*}{$\begin{array}{l}\text { Sub-difference } \\
\text { Median }\end{array}$} \\
\hline & $n$ & Median & $n$ & Median & $n$ & Median & \\
\hline-2 to -1 & 73 & $0.41(0.36)$ & 34 & $0.18(0.52)$ & 40 & $0.29(0.15)$ & $-0.11(0.37)$ \\
\hline-1 to 0 & 73 & $0.57 *\left(0.88^{*}\right)$ & 34 & $1.31 * *(1.38 *)$ & 40 & $0.19(0.83)$ & $1.12(0.55)$ \\
\hline 0 to 1 & 74 & $1.01 * *(0.97 * *)$ & 34 & $0.77 *(1.03 *)$ & 40 & $0.97^{+}(1.44)$ & $-0.20(-0.41)$ \\
\hline 1 to 2 & 68 & $0.80^{*}\left(0.72^{+}\right)$ & 31 & $1.70^{+}(1.26)$ & 39 & $0.23(-1.59)$ & $1.47 *(2.85 *)$ \\
\hline-2 to 0 & 75 & $1.20 *(1.14 *)$ & 34 & $1.75^{*}\left(1.90^{+}\right)$ & 40 & $-0.17(0.85)$ & $1.92(1.05)$ \\
\hline 0 to 2 & 68 & $1.77 * *(1.71 * *)$ & 31 & $2.64 * *(2.44 * *)$ & 39 & $1.51(0.10)$ & $1.13^{+}\left(2.34^{*}\right)$ \\
\hline-2 to 2 & 68 & $2.77 * * *(2.69 * * *)$ & 31 & $2.63 * * *(4.63 * * *)$ & 39 & $0.79(0.89)$ & $1.84 * *(3.74 * *)$ \\
\hline
\end{tabular}

Mean values are presented in parentheses; $t$-statistic for mean and its comparison, Wilcoxon signed-rank $Z$-statistic for median, and Mann-Whitney $Z$-statistic for its comparison

${ }^{+} p<0.10, * p<0.05, * * p<0.01, * * * p<0.001$
While we find the overall positive economic effect of ESIs, we are not overlooking potential contingencies associated with the direct relationship (Aragón-Correa \& Sharma, 2003; Brammer \& Millington, 2008; Orlitzky et al., 2003). A series of studies have shown that whether the economic impact of CSR initiatives is contingent on the type of firm strategy (Gilley et al., 2000), timing of the strategy (Hawn et al., 2018; Jacobs, 2014), firm visibility and resources (Darnall et al., 2010), and capital constraints (Ba et al., 2013). Focusing on ethical sourcing, we advance the body of literature by investigating the joint economic effects of the CSR strategy and the other contextual factors such as initiative timing, firm size, and financial risk. We find that the effectiveness of reactive versus proactive ESIs is relative, depending on such contingencies particularly firm size. Consequently, our findings provide evidence that whether ESIs create shared value (Porter \& Kramer, 2006) or cause potential agency hazards (Davis, 1973; Walley \& Whitehead, 1994) is contingent on how firms best align ESI strategies with the internal and external contextual factors.

\section{Managerial Implications}

For buying firms, our findings provide a strong business case for implementing ESIs. The overall positive economic effect of ESIs underscores them as a means to achieving social responsibility while improving stock market and operating performance. The Starbucks case is one example of this context. Their new, updated sourcing guidelines were designed to improve the needs of both workers and the facilities in the suppliers' local communities. Such ESIs have now reinforced legitimacy from external stakeholders while enhancing supplier productivity (Argenti, 2004; Zachary, 1995). Not to mention stakeholders outside the firm boundary, ESIs' social impact goes beyond buying firms reaching their suppliers and suppliers of suppliers around the globe (Villena, 2019). At the same time, ESIs can also directly enhance supplier management capability, which is crucial for buying firm competitiveness (Blome et al., 2014; Kim et al., 2018). Buying firms should consider this comprehensive utility of ESIs and involve these initiatives more when developing their CSR strategies.

In addition, the findings on the conditional effects of ESIs provide buying firms with practical guidelines on how to maximize firm value while adhering to the social norm. For larger firms, reactive ESIs solicit more positive stock market reactions than proactive ESIs. This means that for larger firms, investors value ESIs that are implemented only when needed more than proactive and substantive ESIs that come with higher control and coordination costs (Baumann-Pauly et al., 2013; Darnall et al., 2010; Wickert et al., 2016). The inevitable costs of substantive ESIs can also make larger firms simply talk rather than walk, which can diminish firm market value (Carlos \& Lewis, 2018; Scheidler et al., 2019). Therefore, we suggest managers consider more specific, operational, problem-solving approaches to ESIs that are more directly linked to value chains (Porter \& Kramer, 2006).

Nevertheless, proactive ESIs do not seem to hurt firm economic performance in any significant way. Especially for smaller firms, we find that the stock market tends to respond positively to proactive ESIs. Investors seem to expect smaller firms to find competitive advantages through innovative initiatives with more flexibility in managing external social challenges. CSR scholars warn that consumers could react negatively when firms engage in more symbolic proactive approaches (Janney \& Gove, 2011; Wagner et al., 2009). To avoid potential corporate hypocrisy, the literature also suggests that firms should spend more on actual CSR initiatives than on advertising those activities (Lamin \& Zaheer, 2012; Wickert et al., 2016; Yoon et al., 2006). Therefore, larger buying firms should clearly define the scope of their ESIs and communicate what specific improvements they can achieve through those proactive ESIs.

Contrary to expectations, our findings also suggest that compared to proactive ESIs, investors in recent times do 
not necessarily prefer reactive ESIs more than the investors in the past. Both ESI strategies seem to keep enhancing shareholder values until recently. In a way, this is good news for firms that are considering different CSR options. Although positive investor reactions to CSR have been weakening over time due to increasing social awareness (Flammer, 2013; Jacobs, 2014), both reactive and proactive ESIs remain viable CSR options to tackle ethical and social problems occurring in supply chains while promoting firm economic performance. Even for highly leveraged firms, investors do not seem to treat reactive and proactive ESIs very differently. Overall, we encourage managers to consider ESIs as an effective CSR option. Noting the nuanced differences between reactive and proactive ESIs for the contextual factors examined will help managers develop even more effective CSR strategies based on ESIs.

\section{Limitations and Future Research Directions}

In this study, we dichotomized corporate ESIs into reactive and proactive initiatives. Although this binary treatment is common in the literature, future research could explore the stock market reactions along the response continuum or different levels of reactiveness and proactiveness in ESIs. Multiple-case studies that categorize ESIs with more granular levels of reactiveness and proactiveness could provide a deeper understanding of how the market reacts to different ESI strategies. Next, our study addressed potential contingencies that we expect to influence the economic effects of ESIs. However, future studies could explore other internal or external contextual factors than initiative timing, firm size, and financial risk, such as supply complexity. It would be also interesting to examine whether and how supply complexity influences the implementation of firms' ESIs and their strategies. Another avenue for future research is to examine the shareholder value effects of firm ESIs in other geographical markets. The perception of investors toward firm ESIs might differ in, for example, Europe and Asia, where future studies can target. We also encourage future research that compares the magnitude of investor reactions among the different markets; a crosscountry event study can assist in providing comprehensive evidence on the economic effect of corporate ESIs.

\section{Conclusion}

Our study examines the economic effect of ESIs measured by shareholder returns with an emphasis on the comparison between reactive and proactive initiatives. We find that overall, the stock market reacts positively to both types of
ESI strategies, while the relative effectiveness of reactive and proactive initiatives is contingent on contextual factors such as firm size. From a longer-term point of view, we further find that overall, firms with reactive ESIs experience greater benefits, particularly regarding operating performance. Collectively, these findings strengthen the business case for ethical sourcing and help firms choose appropriate approaches to ESIs. We expect both scholars and managers to consider ESIs as a valuable strategy to contribute to their social responsibility goals.

\section{Appendix: ESI Events}

\begin{tabular}{|c|c|c|}
\hline Firm name & Type of ESI & Announcement date \\
\hline Boeing Co & Proactive & $4 / 11 / 1989$ \\
\hline ConocoPhillips & Reactive & $5 / 10 / 1990$ \\
\hline Koninklijke Philips N.V & Reactive & $4 / 26 / 1991$ \\
\hline ConocoPhillips & Reactive & $7 / 30 / 1992$ \\
\hline Dow Chemical Co & Reactive & $11 / 3 / 1992$ \\
\hline ConocoPhillips & Reactive & $11 / 20 / 1992$ \\
\hline Ford Motor Co & Proactive & $8 / 26 / 1993$ \\
\hline Altria Group Inc & Reactive & $6 / 15 / 1995$ \\
\hline Starbucks Corp & Proactive & $10 / 23 / 1995$ \\
\hline AK Steel Holding Corp & Reactive & 1/3/1996 \\
\hline AK Steel Holding Corp & Reactive & $5 / 6 / 1996$ \\
\hline Wal-Mart Stores Inc & Reactive & $7 / 16 / 1996$ \\
\hline Ford Motor Co & Reactive & 2/11/1997 \\
\hline Ford Motor Co & Reactive & 2/12/1997 \\
\hline Kate Spade \& Co & Proactive & $4 / 10 / 1997$ \\
\hline Nike Inc & Proactive & 4/10/1997 \\
\hline PVH Corp & Proactive & 4/10/1997 \\
\hline Nike Inc & Reactive & $6 / 25 / 1997$ \\
\hline Nike Inc & Reactive & 9/23/1997 \\
\hline Boeing Co & Proactive & $10 / 21 / 1997$ \\
\hline Mattel Inc & Proactive & $11 / 21 / 1997$ \\
\hline Nike Inc & Reactive & $1 / 15 / 1998$ \\
\hline Nike Inc & Reactive & $5 / 13 / 1998$ \\
\hline Coca-Cola Co & Reactive & $6 / 22 / 1999$ \\
\hline Ford Motor Co & Reactive & $10 / 14 / 1999$ \\
\hline Ford Motor Co & Reactive & $8 / 3 / 2000$ \\
\hline Novartis AG & Proactive & $8 / 4 / 2000$ \\
\hline Ford Motor Co & Reactive & $8 / 25 / 2000$ \\
\hline McDonald's Corp & Reactive & $8 / 28 / 2000$ \\
\hline BP PLC & Proactive & $12 / 21 / 2000$ \\
\hline Chevron Corp & Proactive & $12 / 21 / 2000$ \\
\hline Freeport-McMoran Inc & Proactive & $12 / 21 / 2000$ \\
\hline Rio Tinto PLC & Proactive & $12 / 21 / 2000$ \\
\hline Ford Motor Co & Reactive & $1 / 4 / 2001$ \\
\hline Ford Motor Co & Reactive & $1 / 9 / 2001$ \\
\hline McDonald's Corp & Reactive & $1 / 16 / 2001$ \\
\hline
\end{tabular}




\begin{tabular}{|c|c|c|}
\hline Firm name & Type of ESI & Announcement date \\
\hline McDonald's Corp & Reactive & $1 / 17 / 2001$ \\
\hline McDonald's Corp & Reactive & $3 / 14 / 2001$ \\
\hline McDonald's Corp & Proactive & $4 / 9 / 2001$ \\
\hline Ford Motor Co & Reactive & $11 / 8 / 2001$ \\
\hline Wal-Mart Stores Inc & Proactive & $7 / 7 / 2003$ \\
\hline Koninklijke Philips N.V & Proactive & $3 / 24 / 2004$ \\
\hline Gap Inc & Proactive & $5 / 12 / 2004$ \\
\hline Wal-Mart Stores Inc & Proactive & $6 / 4 / 2004$ \\
\hline Wal-Mart Stores Inc & Proactive & $6 / 7 / 2004$ \\
\hline Gap Inc & Proactive & $7 / 13 / 2005$ \\
\hline Ford Motor Co & Proactive & $9 / 29 / 2005$ \\
\hline BP PLC & Reactive & $10 / 25 / 2005$ \\
\hline Wal-Mart Stores Inc & Reactive & $1 / 19 / 2006$ \\
\hline Apple Inc & Reactive & $6 / 16 / 2006$ \\
\hline Walt Disney Co & Reactive & $7 / 31 / 2006$ \\
\hline Mattel Inc & Reactive & $7 / 31 / 2006$ \\
\hline McDonald's Corp & Reactive & $7 / 31 / 2006$ \\
\hline Yum! Brands Inc & Reactive & $12 / 14 / 2006$ \\
\hline McDonald's Corp & Reactive & $4 / 11 / 2007$ \\
\hline Yum! Brands Inc & Reactive & $4 / 11 / 2007$ \\
\hline BP PLC & Reactive & $5 / 9 / 2007$ \\
\hline Wal-Mart Stores Inc & Reactive & $7 / 25 / 2007$ \\
\hline Mattel Inc & Reactive & $9 / 15 / 2007$ \\
\hline Mattel Inc & Reactive & $9 / 22 / 2007$ \\
\hline J.C. Penney Co & Proactive & $11 / 26 / 2007$ \\
\hline Target Corp & Proactive & $11 / 26 / 2007$ \\
\hline Wal-Mart Stores Inc & Proactive & $11 / 26 / 2007$ \\
\hline Mattel Inc & Proactive & $2 / 19 / 2008$ \\
\hline BP PLC & Reactive & $3 / 5 / 2008$ \\
\hline Nike Inc & Proactive & $3 / 15 / 2008$ \\
\hline Wal-Mart Stores Inc & Proactive & $5 / 14 / 2008$ \\
\hline Colgate-Palmolive Co & Reactive & $5 / 24 / 2008$ \\
\hline PetSmart Inc & Reactive & $5 / 24 / 2008$ \\
\hline Procter \& Gamble Co & Reactive & $5 / 24 / 2008$ \\
\hline Target Corp & Reactive & $5 / 24 / 2008$ \\
\hline Wal-Mart Stores Inc & Reactive & $5 / 24 / 2008$ \\
\hline Chipotle Mexican Grill Inc & Reactive & $6 / 10 / 2008$ \\
\hline Kroger Co & Reactive & $6 / 10 / 2008$ \\
\hline McDonald's Corp & Reactive & $6 / 10 / 2008$ \\
\hline Wal-Mart Stores Inc & Reactive & $6 / 10 / 2008$ \\
\hline BP PLC & Reactive & $7 / 9 / 2008$ \\
\hline Chipotle Mexican Grill Inc & Reactive & $7 / 12 / 2008$ \\
\hline Starbucks Corp & Reactive & $9 / 20 / 2008$ \\
\hline Wal-Mart Stores Inc & Proactive & $10 / 22 / 2008$ \\
\hline ConAgra Foods Inc & Reactive & $1 / 20 / 2009$ \\
\hline General Mills Inc & Reactive & $1 / 20 / 2009$ \\
\hline Kellogg Co & Reactive & $1 / 20 / 2009$ \\
\hline CostcoWholesale Corp & Proactive & $3 / 21 / 2009$ \\
\hline Apple Inc & Proactive & $3 / 1 / 2010$ \\
\hline BP PLC & Reactive & $3 / 17 / 2010$ \\
\hline Microsoft Corp & Reactive & $4 / 16 / 2010$ \\
\hline
\end{tabular}

\begin{tabular}{|c|c|c|}
\hline Firm name & Type of ESI & Announcement date \\
\hline BP PLC & Proactive & $5 / 21 / 2010$ \\
\hline Chevron Corp & Proactive & $5 / 21 / 2010$ \\
\hline Halliburton Co & Proactive & $5 / 21 / 2010$ \\
\hline Royal Dutch Shell Plc & Proactive & $5 / 21 / 2010$ \\
\hline Transocean Ltd & Proactive & $5 / 21 / 2010$ \\
\hline Exxon Mobil Corp & Proactive & $5 / 21 / 2010$ \\
\hline Apple Inc & Reactive & $5 / 27 / 2010$ \\
\hline Hewlett-Packard Co & Reactive & $5 / 27 / 2010$ \\
\hline Nokia Corp & Reactive & $5 / 27 / 2010$ \\
\hline Apple Inc & Reactive & $7 / 22 / 2010$ \\
\hline Nokia Corp & Reactive & $7 / 22 / 2010$ \\
\hline BP PLC & Reactive & $8 / 13 / 2010$ \\
\hline Apple Inc & Reactive & $8 / 19 / 2010$ \\
\hline Nokia Corp & Reactive & $8 / 19 / 2010$ \\
\hline Apple Inc & Reactive & 9/7/2010 \\
\hline Hewlett-Packard Co & Reactive & $9 / 7 / 2010$ \\
\hline Nokia Corp & Reactive & 9/7/2010 \\
\hline BP PLC & Reactive & 9/9/2010 \\
\hline BP PLC & Reactive & 9/30/2010 \\
\hline BP PLC & Reactive & $10 / 29 / 2010$ \\
\hline BP PLC & Proactive & $2 / 1 / 2011$ \\
\hline Apple Inc & Proactive & $2 / 15 / 2011$ \\
\hline BP PLC & Reactive & $6 / 21 / 2011$ \\
\hline Apple Inc & Proactive & $8 / 3 / 2011$ \\
\hline Sony Corp & Proactive & $8 / 3 / 2011$ \\
\hline Johnson \& Johnson & Reactive & $12 / 24 / 2011$ \\
\hline Boeing Co & Proactive & $12 / 30 / 2011$ \\
\hline Apple Inc & Reactive & $2 / 14 / 2012$ \\
\hline Apple Inc & Proactive & $4 / 6 / 2012$ \\
\hline Wal-Mart Stores Inc & Reactive & $8 / 24 / 2012$ \\
\hline AngloGold Ashanti Ltd & Reactive & $10 / 10 / 2012$ \\
\hline Gold Field Ltd & Reactive & $10 / 10 / 2012$ \\
\hline Harmony Gold Mining Ltd & Reactive & $10 / 10 / 2012$ \\
\hline Nike Inc & Proactive & $11 / 30 / 2012$ \\
\hline Wal-Mart Stores Inc & Proactive & $12 / 28 / 2012$ \\
\hline Yum! Brands Inc & Reactive & $1 / 11 / 2013$ \\
\hline Wal-Mart Stores Inc & Proactive & $1 / 22 / 2013$ \\
\hline Hewlett-Packard Co & Proactive & $2 / 11 / 2013$ \\
\hline Yum! Brands Inc & Reactive & $2 / 26 / 2013$ \\
\hline Gap Inc & Proactive & $4 / 25 / 2013$ \\
\hline Nike Inc & Proactive & $4 / 25 / 2013$ \\
\hline The Children's Place Inc & Reactive & $4 / 25 / 2013$ \\
\hline Sears Holdings Corp & Reactive & $5 / 10 / 2013$ \\
\hline Wal-Mart Stores Inc & Reactive & $5 / 10 / 2013$ \\
\hline Gap Inc & Reactive & $5 / 15 / 2013$ \\
\hline J.C. Penney Co & Reactive & $5 / 15 / 2013$ \\
\hline Sears Holdings Corp & Reactive & $5 / 15 / 2013$ \\
\hline Wal-Mart Stores Inc & Reactive & $5 / 15 / 2013$ \\
\hline Gap Inc & Reactive & $6 / 27 / 2013$ \\
\hline Macy's Inc & Reactive & $6 / 27 / 2013$ \\
\hline Sears Holdings Corp & Reactive & $6 / 27 / 2013$ \\
\hline
\end{tabular}




\begin{tabular}{lll}
\hline Firm name & Type of ESI & Announcement date \\
\hline Target Corp & Reactive & $6 / 27 / 2013$ \\
VF Corp & Reactive & $6 / 27 / 2013$ \\
Wal-Mart Stores Inc & Reactive & $6 / 27 / 2013$ \\
Gap Inc & Proactive & $10 / 23 / 2013$ \\
Wal-Mart Stores Inc & Proactive & $10 / 23 / 2013$ \\
Tyson Foods Inc & Proactive & $12 / 10 / 2013$ \\
Whole Foods Market Inc & Proactive & $12 / 19 / 2013$ \\
Wal-Mart Stores Inc & Reactive & $1 / 27 / 2014$ \\
Wal-Mart Stores Inc & Reactive & $1 / 29 / 2014$ \\
Gap Inc & Proactive & $2 / 20 / 2014$ \\
General Motors Corp & Reactive & $3 / 18 / 2014$ \\
General Motors Corp & Reactive & $3 / 27 / 2014$ \\
Wal-Mart Stores Inc & Proactive & $4 / 14 / 2014$ \\
General Motors Corp & Reactive & $5 / 7 / 2014$ \\
General Motors Corp & Proactive & $5 / 8 / 2014$ \\
General Motors Corp & Reactive & $6 / 5 / 2014$ \\
General Motors Corp & Proactive & $6 / 13 / 2014$ \\
Wal-Mart Stores Inc & Proactive & $6 / 18 / 2014$ \\
General Motors Corp & Reactive & $6 / 25 / 2014$ \\
McDonald's Corp & Reactive & $7 / 25 / 2014$ \\
General Motors Corp & Reactive & $7 / 31 / 2014$ \\
\hline
\end{tabular}

\section{Declarations}

Conflict of interest The authors declare that they have no conflict of interest.

Ethical Approval This study uses publicly available secondary data.

Informed Consent Informed consent are not required by the universities of the authors.

Open Access This article is licensed under a Creative Commons Attribution 4.0 International License, which permits use, sharing, adaptation, distribution and reproduction in any medium or format, as long as you give appropriate credit to the original author(s) and the source, provide a link to the Creative Commons licence, and indicate if changes were made. The images or other third party material in this article are included in the article's Creative Commons licence, unless indicated otherwise in a credit line to the material. If material is not included in the article's Creative Commons licence and your intended use is not permitted by statutory regulation or exceeds the permitted use, you will need to obtain permission directly from the copyright holder. To view a copy of this licence, visit http://creativecommons.org/licenses/by/4.0/.

\section{References}

Alexander, G. J., \& Buchholz, R. A. (1978). Corporate social responsibility and stock market performance. Academy of Management Journal, 21(3), 479-486.
Andersen, M., \& Skjoett-Larsen, T. (2009). Corporate social responsibility in global supply chains. Supply Chain Management: an International Journal, 14(2), 75-86.

Aragón-Correa, J. A., Hurtado-Torres, N., Sharma, S., \& GarcíaMorales, V. J. (2008). Environmental strategy and performance in small firms: A resource-based perspective. Journal of Environmental Management, 86(1), 88-103.

Aragón-Correa, J. A., \& Sharma, S. (2003). A contingent resourcebased view of proactive corporate environmental strategy. Academy of Management Review, 28(1), 71-88.

Argenti, P. A. (2004). Collaborating with activists: How Starbucks works with NGOs. California Management Review, 47(1), 91-116.

Arora, P., Hora, M., Singhal, V., \& Subramanian, R. (2020). When do appointments of corporate sustainability executives affect shareholder value? Journal of Operations Management, 66(4), 464-487.

Artiach, T., Lee, D., Nelson, D., \& Walker, J. (2010). The determinants of corporate sustainability performance. Accounting \& Finance, 50(1), 31-51.

Awaysheh, A., \& Klassen, R. D. (2010). The impact of supply chain structure on the use of supplier socially responsible practices. International Journal of Operations \& Production Management, 30(12), 1246-1268.

Ba, S. L., Lisic, L. L., Liu, Q. D., \& Stallaert, J. (2013). Stock market reaction to green vehicle innovation. Production and Operations Management, 22(4), 976-990.

Banjo, S. (2013). Wal-Mart, Gap press for safety in Bangladesh. The Wall Street Journal, 23 October, B2.

Banjo, S., Zimmerman, A., \& Kapner, S. (2013). Wal-Mart crafts own Bangladesh safety plan. The Wall Street Journal, May 15, B1.

Barber, B. M., \& Lyon, J. D. (1996). Detecting abnormal operating performance: The empirical power and specification of test statistics. Journal of Financial Economics, 41(3), 359-399.

Barnea, A., \& Rubin, A. (2010). Corporate social responsibility as a conflict between shareholders. Journal of Business Ethics, 97(1), 71-86.

Barone, M. J., Miyazaki, A. D., \& Taylor, K. A. (2000). The influence of cause-related marketing on consumer choice: does one good turn deserve another? Journal of the Academy of Marketing Science, 28(2), 248-262.

Batson, A. (2006). McDonald's, Mattel dispute allegations about Chinese plant. The Wall Street Journal, 31 July, B6.

Baumann-Pauly, D., Wickert, C., Spence, L. J., \& Scherer, A. G. (2013). Organizing corporate social responsibility in small and large firms: Size matters. Journal of Business Ethics, 115, 693-705.

Becker-Olsen, K. L., Cudmore, B. A., \& Hill, R. P. (2006). The impact of perceived corporate social responsibility on consumer behavior. Journal of Business Research, 59(1), 46-53.

Berens, G., Van Riel, C. B., \& Van Bruggen, G. H. (2005). Corporate associations and consumer product responses: The moderating role of corporate brand dominance. Journal of Marketing, 69(3), 35-48.

Bhattacharya, C. B., Korschun, D., \& Sen, S. (2009). Strengthening stakeholder-company relationships through mutually beneficial corporate social responsibility initiatives. Journal of Business Ethics, 85(2), 257-272.

Blome, C., Hollos, D., \& Paulraj, A. (2014). Green procurement and green supplier development: Antecedents and effects on supplier performance. International Journal of Production Research, 52(1), 32-49.

Brammer, S., \& Millington, A. (2008). Does it pay to be different? An analysis of the relationship between corporate social and financial performance. Strategic Management Journal, 29(12), $1325-1343$. 
Brown, S. J., \& Warner, J. B. (1985). Using daily stock returns-The case of event studies. Journal of Financial Economics, 14(1), $3-31$.

Browning, J., \& Zabriskie, N. B. (1983). How ethical are industrial buyers? Industrial Marketing Management, 12(4), 219-224.

Burkitt, L. (2014). Wal-Mart boosts its vendor compliance in China following criticism. The Wall Street Journal, January 29, B9.

Capelle-Blancard, G., \& Laguna, M.-A. (2010). How does the stock market respond to chemical disasters? Journal of Environmental Economics and Management, 59, 192-205.

Carhart, M. M. (1997). On persistence in mutual fund performance. Journal of Finance, 52(1), 57-82.

Carlos, W. C., \& Lewis, B. W. (2018). Strategic Silence: Withholding certification status as a hypocrisy avoidance tactic. Administrative Science Quarterly, 63(1), 130-169.

Carter, C. R., \& Jennings, M. M. (2002). Logistics social responsibility: An integrative framework. Journal of Business Logistics, 23(1), 145-180.

Carter, C. R., Kale, R., \& Grimm, C. M. (2000). Environmental purchasing and firm performance: An empirical investigation. Transportation Research Part E: Logistics and Transportation Review, 36(3), 219-228.

Chen, J.-Y., \& Baddam, S. R. (2015). The effect of unethical behavior and learning on strategic supplier selection. International Journal of Production Economics, 167, 74-87.

Chen, L., Yao, S., \& Zhu, K. (2020). Responsible sourcing under supplier-auditor collusion. Manufacturing \& Service Operations Management, 22(6), 1234-1250.

Chen, Y., Ganesan, S., \& Liu, Y. (2009). Does a firm's product-recall strategy affect its financial value? An examination of strategic alternatives during product-harm crises. Journal of Marketing, 73(6), 214-226.

Cohen, J. (1960). A coefficient of agreement for nominal scales. Educational and Psychological Measurement, 20(1), 37-46.

Dam, L., \& Petkova, B. (2014). The impact of environmental supply chain sustainability programs on shareholder wealth. International Journal of Operations \& Production Management, 34(5), 586-609.

Darnall, N., Henriques, I., \& Sadorsky, P. (2010). Adopting proactive environmental strategy: The influence of stakeholders and firm size. Journal of Management Studies, 47(6), 1072-1094.

Davis, K. (1973). The case for and against business assumption of social responsibilities. Academy of Management Journal, 16(2), 312-322.

De Pelsmacker, P., Driesen, L., \& Rayp, G. (2005). Do consumers care about ethics? Willingness to pay for fair-trade coffee. Journal of Consumer Affairs, 39(2), 363-385.

Dean, J., \& Tsai, T.-I. (2010). Apple, H-P to examine Asian supplier after string of deaths at factory. The Wall Street Journal, 27 May, B1.

Dorobantu, S., Henisz, W. J., \& Nartey, L. (2017). Not all sparks light a fire: Stakeholder and shareholder reactions to critical events in contested markets. Administrative Science Quarterly, 62(3), 561-597.

Eccles, R. G., Ioannou, I., \& Serafeim, G. (2014). The impact of corporate sustainability on organizational processes and performance. Management Science, 60(11), 2835-2857.

Eccles, R. G., Newquist, S. C., \& Schatz, R. (2007). Reputation and its risks. Harvard Business Review, 85(2), 104.

Fama, E. F. (1970). Efficient capital markets: A review of theory and empirical work. Journal of Finance, 25(2), 383-417.

Fama, E. F., \& French, K. R. (1993). Common risk-factors in the returns on stocks and bonds. Journal of Financial Economics, 33(1), 3-56.

Fiksel, J. (1997). Competitive advantage through environmental excellence. Corporate Environmental Strategy, 4(4), 55-62.
Flammer, C. (2013). Corporate social responsibility and shareholder reaction: The environmental awareness of investors. Academy of Management Journal, 56(3), 758-781.

Foerstl, K., Reuter, C., Hartmann, E., \& Blome, C. (2010). Managing supplier sustainability risks in a dynamically changing environment-Sustainable supplier management in the chemical industry. Journal of Purchasing and Supply Management, 16(2), 118-130.

Frenkel, S. J., \& Scott, D. (2002). Compliance, collaboration, and codes of labor practice: The Adidas connection. California Management Review, 45(1), 29-49.

Gilley, K. M., Worrell, D. L., Davidson, W. N., \& El-Jelly, A. (2000). Corporate environmental initiatives and anticipated firm performances: The differential effects of process-driven versus product-driven greening initiatives. Journal of Management, 26(6), 1199-1216.

Gilson, S. C. (1990). Bankruptcy, boards, banks, and blockholders: Evidence on changes in corporate ownership and control when firms default. Journal of Financial Economics, 27(2), 355-387.

Groza, M. D., Pronschinske, M. R., \& Walker, M. (2011). Perceived organizational motives and consumer responses to proactive and reactive CSR. Journal of Business Ethics, 102(4), 639-652.

Hawn, O., Chatterji, A. K., \& Mitchell, W. (2018). Do investors actually value sustainability? New evidence from investor reactions to the Dow Jones Sustainability Index (DJSI). Strategic Management Journal, 39(4), 949-976.

Heckman, J. J. (1979). Sample selection bias as a specification error. Econometrica, 47(1), 153-161.

Hendricks, K. B., Hora, M., \& Singhal, V. R. (2015). An empirical investigation on the appointments of supply chain and operations management executives. Management Science, 61, 1562-1583.

Hendricks, K. B., Jacobs, B. W., \& Singhal, V. R. (2020). Stock market reaction to supply chain disruptions from the 2011 Great East Japan earthquake. Manufacturing \& Service Operations Management, 22(4), 683-699.

Humphreys, P. K., Li, W., \& Chan, L. (2004). The impact of supplier development on buyer-supplier performance. Omega, 32(2), 131-143.

Jacobs, B. W. (2014). Shareholder value effects of voluntary emissions reduction. Production and Operations Management, 23(11), 1859-1874.

Jacobs, B., \& Singhal, V. R. (2017). The effect of the Rana Plaza disaster on shareholder wealth of retailers: Implications for sourcing strategies and supply chain governance. Journal of Operations Management, 49-51, 52-66.

Janney, J. J., \& Gove, S. (2011). Reputation and corporate social responsibility aberrations, trends, and hypocrisy: Reactions to firm choices in the stock option backdating scandal. Journal of Management Studies, 48(7), 1562-1585.

Jiang, B. (2009). The effects of interorganizational governance on supplier's compliance with SCC: An empirical examination of compliant and non-compliant suppliers. Journal of Operations Management, 27(4), 267-280.

Kang, C., Germann, F., \& Grewal, R. (2016). Washing away your sins? Corporate social responsibility, corporate social irresponsibility, and firm performance. Journal of Marketing, 80(2), 59-79.

Kaul, A., \& Luo, J. (2018). An economic case for CSR: The comparative efficiency of for-profit firms in meeting consumer demand for social goods. Strategic Management Journal, 39(6), 1650-1677.

Kim, S., Colicchia, C., \& Menachof, D. (2018). Ethical sourcing: An analysis of the literature and implications for future research. Journal of Business Ethics, 152(4), 1033-1052.

Kim, S., Wagner, S. M., \& Colicchia, C. (2019). The impact of supplier sustainability risk on shareholder value. Journal of Supply Chain Management, 55(1), 71-87.

Kim, Y. S., \& Choi, Y. (2012). College students' perception of Philip Morris's tobacco-related smoking prevention and 
tobacco-unrelated social responsibility. Journal of Public Relations Research, 24(2), 184-199.

Klassen, R. D., \& McLaughlin, C. P. (1996). The impact of environmental management on firm performance. Management Science, 42(8), 1199-1214.

Knudsen, J. S. (2013). The Growth of Private Regulation of Labor Standards in Global Supply Chains: Mission Impossible for Western Small-and Medium-Sized Firms? Journal of Business Ethics, 117(2), 387-398.

Kothari, S. P., \& Warner, J. B. (2007). Econometrics of event studies. Handbook of Corporate Finance: Empirical Corporate Finance, 1, 3-36.

Kraus, A., \& Litzenberger, R. H. (1973). A state-preference model of optimal financial leverage. Journal of Finance, 28(4), 911-922.

Krause, D. R., Scannell, T. V., \& Calantone, R. J. (2000). A structural analysis of the effectiveness of buying firms' strategies to improve supplier performance. Decision Sciences, 31(1), 33-55.

Lamin, A., \& Zaheer, S. (2012). Wall Street vs. Main Street: Firm strategies for defending legitimacy and their Impact on different stakeholders. Organization Science, 23(1), 47-66.

Lewis, B. W., \& Carlos, W. C. (2019). The risk of being ranked: Investor response to marginal inclusion on the 100 Best Corporate Citizens list. Strategic Management Journal. https://doi.org/10. 1002/smj.3083

Locke, R. M., \& Romis, M. (2007). Improving work conditions in a global supply chain. MIT Sloan Management Review, 48(2), $54-62$.

Luo, X., \& Bhattacharya, C. B. (2006). Corporate social responsibility, customer satisfaction, and market value. Journal of Marketing, 70(4), 1-18.

MacKinlay, A. C. (1997). Event studies in economics and finance. Journal of Economic Literature, 35(1), 13-39.

Marchant, B. (2017). Life and death in Apple's forbidden city. The Guardian, 18 June.

McWilliams, A., \& Siegel, D. (1997). Event studies in management research: Theoretical and empirical issues. Academy of Management Journal, 40(3), 626-657.

McWilliams, A., \& Siegel, D. (2001). Corporate social responsibility: A theory of the firm perspective. Academy of Management Review, 26(1), 117-127.

Mishra, S., \& Modi, S. B. (2016). Corporate social responsibility and shareholder wealth: The role of marketing capability. Journal of Marketing, 80(1), 26-46.

Nisen, M. (2013). How Nike solved its sweatshop problem, Business Insider, 9.

Orlitzky, M., Schmidt, F. L., \& Rynes, S. L. (2003). Corporate social and financial performance: A meta-analysis. Organization Studies, 24(3), 403-441.

Porter, M. E. (1985). Creating and sustaining superior performance. The Free Press.

Porter, M. E., \& Kramer, M. R. (2006). Strategy and society: The link between competitive advantage and corporate social responsibility. Harvard Business Review, 84(12), 78-92.

Porter, M. E., \& Van der Linde, C. (1995). Toward a new conception of the environment-competitiveness relationship. Journal of Economic Perspectives, 9(4), 97-118.

Preuss, L. (2009). Ethical sourcing codes of large UK-based corporations: Prevalence, content, limitations. Journal of Business Ethics, 88(4), 735-747.

Reuter, C., Foerstl, K., Hartmann, E., \& Blome, C. (2010). Sustainable global supplier management: The role of dynamic capabilities in achieving competitive advantage. Journal of Supply Chain Management, 46(2), 45-63.

Roberts, S. (2003). Supply chain specific? Understanding the patchy success of ethical sourcing initiatives. Journal of Business Ethics, 44(2), 159-170.
Rudelius, W., \& Buchholz, R. A. (1979). Ethical problems of purchasing managers. Harvard Business Review, 57(2), 8-14.

Ruland, W., \& Zhou, P. (2005). Debt, diversification, and valuation. Review of Quantitative Finance and Accounting, 25(3), 277-291.

Sadovnikova, A., \& Pujari, A. (2017). The effect of green partnerships on firm value. Journal of the Academy of Marketing Science, 45(2), 251-267.

Scheidler, S., Edinger-Schons, L. M., Spanjol, J., \& Wieseke, J. (2019). Scrooge posing as Mother Teresa: How hypocritical social responsibility strategies hurt employees and firms. Journal of Business Ethics, 157, 339-358.

Shevchenko, A., Lévesque, M., \& Pagell, M. (2016). Why firms delay reaching true sustainability. Journal of Management Studies, 53(5), 911-935.

Skarmeas, D., \& Leonidou, C. N. (2013). When consumers doubt, watch out! The role of CSR skepticism. Journal of Business Research, 66(10), 1831-1838.

Spence, L., \& Bourlakis, M. (2009). The evolution from corporate social responsibility to supply chain responsibility: The case of Waitrose. Supply Chain Management: an International Journal, 14(4), 291-302.

Trudel, R., \& Cotte, J. (2009). Does it pay to be good? MIT Sloan Management Review, 50(2), 61.

Ullmann, A. A. (1985). Data in search of a theory: A critical examination of the relationships among social performance, social disclosure, and economic performance of US firms. Academy of Management Review, 10(3), 540-557.

Villena, V. H. (2019). The missing link? The strategic role of procurement in building sustainable supply networks. Production and Operations Management, 28(5), 1149-1172.

Wagner, T., Lutz, R. J., \& Weitz, B. A. (2009). Corporate hypocrisy: Overcoming the threat of inconsistent corporate social responsibility perceptions. Journal of Marketing, 73(6), 77-91.

Walley, N., \& Whitehead, B. (1994). It's not easy being green. Harvard Business Review, 72(3), 46-52.

White, K., MacDonnell, R., \& Ellard, J. H. (2012). Belief in a just world: Consumer intentions and behaviors toward ethical products. Journal of Marketing, 76(1), 103-118.

Wickert, C., Scherer, A. G., \& Spence, L. J. (2016). Walking and talking corporate social responsibility: Implications of firm size and organizational cost. Journal of Management Studies, 53(7), $1169-1196$.

WSJ. (1997). Nike cancels pacts with Indonesia plants over wage policies. The Wall Street Journal, 23 September, A6.

WSJ. (2004). Philips Electronics NV: Suppliers will be required to observe labor standards. The Wall Street Journal, 24 March, A8.

Yoon, Y., Gurhan-Canli, Z., \& Schwarz, N. (2006). The effect of corporate social responsibility (CSR) activities on companies with bad reputations. Journal of Consumer Psychology, 16(4), 377-390.

$\mathrm{Yu}, \mathrm{X}$. (2008). Impacts of corporate code of conduct on labor standards: A case study of Reebok's athletic footwear supplier factory in China. Journal of Business Ethics, 81(3), 513-529.

Zachary, G. P. (1995). Starbucks adopts guidelines to improve conditions for foreign coffee workers. The Wall Street Journal, 23 October, B4.

Zadek, S. (2004). The path to corporate responsibility. Harvard Business Review, 82(12), 125-132.

Zimmerman, A., \& Fong, M. (2008). Chinese suppliers face new WalMart mandates. The Wall Street Journal, 22 October, B1.

Publisher's Note Springer Nature remains neutral with regard to jurisdictional claims in published maps and institutional affiliations. 